Ritrýnd grein birt 27. ágúst 2021

\title{
Sköpunar- og tæknismiðjur í premur grunnskólum: Framkvæmd og kennslufræði fyrstu skrefin
}

\author{
Svanborg R. Jónsdóttir, Skúlína H. Kjartansdóttir, \\ Svala Jónsdóttir, Svava Pétursdóttir og Torfi Hjartarson \\ Abstract $\backslash$ Um höfunda About the authors $>$ Heimildir
}

\begin{abstract}
Samtíminn er fullur af móthverfum sem fela í sér ógnir og tækifæri, álitamál og áskoranir. Nútímasamfélag kallar á skólastarf, par sem nemendur eru virkir og skapandi pátttakendur, færir um að móta eigið nám. Pessi rannsókn segir frá fyrsta ári af premur í próunarverkefni priggja grunnskóla í Reykjavík um sköpunar- og tæknismiðjur (e. makerspaces). Hún á að auka skilning á hvað parf til að nýsköpun og hönnun í anda sköpunarsmiðja skjóti rótum í starfi grunnskóla og á hvaða uppeldis- og kennslufræði par er byggt. Leitast er við að greina hvað helst einkenndi og hafði áhrif á innleiðingu tæknilausna, nemendavinnu og kennsluhátta í peim anda. Byggt er á eigindlegri nálgun og reynt að fá innsýn í reynslu fólks, viðhorf og hugsun í verkefninu. Rannsóknargögn samanstanda af vettvangsathugunum, viðtölum við skólastjórnendur, verkefnisstjóra og teymi kennara í skólunum premur, auk styrkumsóknar, upplýsingavefs og síðu Facebook-hóps. Lýst er hvernig margir pættir spila saman og takast á við framgang verkefnisins ásamt tilraunum kennara á peim grunni. Ekki síst er athygli beint að hugmyndum um kennslu og eflandi kennslufræði sem par birtast eða búa að baki. Viðhorf og stuðningur skólastjórnenda, starf verkefnisstjóranna, viðhorf, reynsla og færni kennara, skilningur á verkefninu og mikilvægi pess, skipulag stundaskrár, samtal og samstaða eru pættir sem virðast skipta máli í innleiðingunni en einnig sérstaða einstakra skóla auk hefðar fyrir pemanámi pvert á greinasvið, teymiskennslu og skapandi starfi. Mörg uppbyggileg skref voru stigin á pessu fyrsta ári sem parf að fylgja eftir með virku samtali og samvirkni pessara pátta.
\end{abstract}

Efnisorð: Sköpun, sköpunarsmiðjur, eflandi kennslufræði, stafræn tækni, próunarverkefni, menntabúðir

\section{Inngangur}

Í samfélagi samtímans er pörf á skólakerfi og skólastarfi par sem nám er einstaklingsmiðað og eflir atbeina nemenda, kveikir áhuga og byggir á samvinnu, samskiptum og nýsköpun. Nemendur eiga sem oftast að glíma við verkefni og afla jafnharðan upplýsinga sem parf til að fást við pau. Petta kallar á skólastarf par sem nemendur eru skapandi pátttakendur og búa yfir atbeina til að móta eigið nám (Gerður G. Óskarsdóttir, 2014; Litts, 2015; Priestley og Biesta, 2013; Svanborg R. Jónsdóttir og Rósa Gunnarsdóttir, 2017). Hæfnimiðaðar (e. competence based) námskrár endurspegla pessar hugmyndir og starf í sköpunarsmiðjum (e. makerspaces) er í sama anda, pær eiga að efla sköpun og aðra mikilsverða hæfni 21. aldar. Í sköpunarsmiðjum eru efniviður, verkfæri og gögn sem auðvelda skólafólki að koma til móts við fjölbreyttan nemendahóp eftir nýjum leiðum par sem reynir á sjálfstæða verkefnavinnu og lausnaleit (Blum-Ross o.fl., 2019). 
Starfsfólk grunnskóla austast og vestast í Reykjavík; Ingunnarskóla, Selásskóla og Vesturbæjarskóla (2019), hóf um mitt ár 2019 samstarf um innleiðingu og próun sköpunarsmiðja við skólana prjá. Byggt var á próunarstyrk frá Reykjavíkurborg og samstarfi við rannsakendur á Menntavísindasviði Háskóla Íslands, höfunda pessarar greinar. Î styrkumsókn skólanna priggja kemur fram að skólasamfélagið, skólayfirvöld og foreldrar kalli eftir námsumhverfi sem stuðlar að pekkingu og færni til nýsköpunar. Vonast er til að rannsóknin auki skilning skólafólks, yfirvalda og almennings á pví sem parf til að nýsköpun og hönnunarhugsun í anda sköpunarsmiðja skjóti rótum í starfi grunnskóla, ekki síst peirri uppeldis- og kennslufræði sem par býr að baki. Rannsakendur styðja átak Reykjavíkurborgar í pessum efnum og viðleitni skólanna priggja til próunar og nýbreytni í skólastarfi. Leitað er svara við hvað einkenni fyrstu skref próunarstarfsins, innleiðingu og kennsluhætti fyrsta árið sem verkefnið varir og hvað helst hafi áhrifá framgang pess. Lögð er áhersla á að greina upplifun og skilning starfsfólks á innleiðingu peirra kennsluhátta sem einkenna sköpunarsmiðjur, að hvaða marki peir eru eflandi fyrir nemendur og leyfa eitthvert val um viðfangsefni og aðferð. Búist er við að niðurstöðurnar nýtist í kennaramenntun og auki pekkingu á próun kennsluhátta. Einnig eiga pær að gagnast skólafólki í skapandi skólastarfi og auðvelda pví að forðast áhættupætti við innleiðingu nýjunga.

\section{Fræðilegur bakgrunnur}

Varanlegar og djúpar breytingar í skólastarfi hafa reynst torveldar og háðar mörgum og oft lítt sýnilegum páttum (Fullan, 2019; Mason, 2008). Hér verður fjallað um nokkra pætti sem gætu haft áhrif á innleiðingu sköpunarsmiðja í skólastarf í ljósi rannsókna og starfshátta í íslenskum grunnskólum.

\section{Sköpun og skólastarf}

Allt frá miðri síðustu öld hafa víða komið fram pau sjónarmið að rækta purfi sköpunarpáttinn í menntun (Craft, 2001). Fræðafólk hefur fært fyrir pví rök að vegna efnahagslegra, félagslegra og umhverfislegra áskorana purfi að efla skapandi hugsun og athafnagetu (Craft, 2001; Montuori, 2012; Sardar, 2010). Sköpun og nýsköpun eru meðal færnipátta sem rannsakendur telja brýna á 21. öld, ásamt gagnrýninni hugsun og lausnaleitarnámi, hæfni í ákvarðanatöku og hugvitund (Binkley o.fl., 2012). Einnig er bent á færni í samskiptum og samvinnu, tæknilæsi og beitingu upplýsingatækni, ásamt lífsleikni, borgaravitund og samfélagsábyrgð. Á Î́landi voru innleiddir grunnpættir menntunar pvert á greinasvið (Mennta- og menningarmálaráðuneyti, 2012) en í skýringarriti um grunnpáttinn sköpun segir að sköpun felist í að búa til eitthvað sem er frumlegt, byggi á hugarflugi og hafi gildi fyrir okkur sjálf, okkar nánasta umhverfi eða samfélagið í víðara samhengi (Ingibjörg Jóhannsdóttir o.fl., 2012).

Margir hafa glímt við hvað felist í að vera skapandi (sjá t.d. Craft, 2001 og Walia, 2019) en oft er stuðst við pá almennu skilgreining að pað sé getan til að koma fram með eða nýta frumlegar og óvenjulegar hugmyndir (Runco og Jaeger, 2012; Sternberg og Lubart, 2002). Walia (2019) dregur fram að ekki megi binda sig við eitt algilt sjónarhorn á sköpun heldur purfi rannsakendur að beita sveigjanlegri nálgun til að skilja samvirkni pátta í sköpunarferli. Einstein sagði í viðtali árið 1929: „Pekking er takmörkunum háð en ímyndunaraflið nær utan um allt í heiminum“ (eftir Viereck, 1929, bls. 117).

Eisner (2002) taldi bóknámsgreinar geta lært mikið af hugsun að baki listkennslu. Í listkennslu væri unnið með fjölbreytilegar lausnir og talið mikilvægt að verk nemenda væru persónuleg. Með áherslu á staðreyndir og rétt svör væri verið að bæla niður dýrmæta eiginleika ungra barna. Fá pyrfti börnum verkefni par sem pau fengju innri umbun, hefðu val, gætu gleymt sér í ferlinu og fundið ánægju við vinnu sína. Annað sem væri mikilvægt í listnámi væri sveigjanleiki og útkoman væri oft ekki ljós fyrirfram. Nemendur ættu að fá tækifæri til að staldra við og upplifa. 
Við úttekt á umfangi og gæðum list- og menningarfræðslu á Íslandi (Bamford, 2011) kom fram að starfsfólki leikskóla tækist vel að flétta sköpun inn í alla námspætti en á öðrum skólastigum mætti starfsfólk standa sig betur. Listkennsla á Íslandi virtist víðast á háu plani en lítið um skapandi starf í öðrum greinum, nemendur næðu ekki að yfirfæra færni sína í sköpun til greinasviða eins og náttúrufræða, stærðfræði og bókmennta. Andrúmsloft í íslenskum skólum væri opið og pví ætti að vera auðveldara að innleiða skapandi kennsluhætti hér á landi en í löndum par sem skólakerfið er í fastari skorðum (Bamford, 2011).

\section{Sköpunarsmiðjur}

Sköpunarsmiðjur byggja á peirri hugmynd að ýta purfi undir sköpun og margvíslega hæfni með stuðningi stafrænnar tækni, til að efla færni og próa pekkingu sem dugar til að finna leiðir í flóknum tækniheimi nútímans (Marsh o.fl., 2017). Pá hugmynd ber líka hátt í skólastarfi og á sér par stoð í fræðum uppeldisfræðinga á borð við Dewey, Papert og Freire, sem töldu að skapa byrfti skilyrði par sem nemendur gætu nýtt áhuga sinn og reynslu og proskað í verki (Blikstein, 2013). Smiðjurnar eru rými par sem vinna má með sérhæfð verkfæri, eins og rafeindatækni, geislaskera og prívíddarprentara, og ýmsan efnivið, stafrænan og hefðbundinn (Marsh o.fl., 2017). Pær eru vettvangur hönnunar á smíðisgripum og vörum en taka einnig til forritunar og stafrænnar miðlunar. Púsundir barna og fullorðinna fylla nú slíkar smiðjur um allan heim til að nýta sameiginlegan sköpunarkraft og hugvit (Halverson og Sheridan, 2014). Smiðjurnar eiga að byggja upp samfélög framtíðarfrumkvöðla um færni 21. aldar; efla fjölháttalæsi, tæknilega rökhugsun, prautalausnafærni og samvinnu (Litts, 2015), koma til móts við fjölbreyttan notendahóp og gera nemendum í skóla fært að uppgötva og proska hæfileika sína. Sköpunarsmiðjur bjóða upp á sampættingu og tengingar pvert á námsgreinar enda er sköpun ekki námsgreinabundin (Marsh o.fl., 2017). Sköpun er pá páttur í persónumiðaðari framleiðslu (e. personalisation of production) par sem atbeini einstaklinga fær notið sín við að búa til eitthvað sem svarar pörfum peirra eða hugmyndum (Gershenfeld, 2012). Nýlegar rannsóknir Kumpulainen og Kajamaa (2021) gefa til kynna að skólasköpunarsmiðjur geti umbreytt skólastarfi en jafnframt skapað spennu og áskoranir milli hefða og nýbreytni, kennarastýrðrar kennslu og frumkvæðis nemenda. Fram úr pví megi pó ráða með samvinnu og stöðuga viðleitni til skólapróunar að leiðarljósi.

Próun sköpunarsmiðja í byrjun 21. aldar (Gershenfeld, 2012) á rætur að rekja til tölvuvæðingar, tölvustýrðra véla og prentunar í prívídd. Breyta mátti gögnum í hluti og auka nákvæmni, fjölbreytileika og hraða í hönnun og framleiðslu. Almenn tölvueign bauð enn fremur upp á að almenningur gæti komið að pessum ferlum og tekið sér sérfræðings- og framleiðsluhlutverk. Undir aldamótin hafði stafræn tækni lætt sér inn í daglegt líf fólks og segja mátti að fólk hefði gengið stafrænni tækni á hönd (Negroponte, 1995). Sköpunarsmiðjur um stafræna tækni spruttu fram litlu síðar, alpjóðleg hreyfing áhugafólks um tækni og menntun.

Stjórnvöld höfðu víða ýtt út verkgreinum og skólakerfi verið treg til að sinna nýrri tækni og nýsköpun. Fyrsta fab lab-smiðjan var stofnuð árið 2003 af MIT Center of Bits and Atoms, teymi Sherry Lassiter í South End Technology Center í Boston og fljótlega spruttu upp slíkar smiðjur um allan heim (Gershenfeld, 2012). Í hreyfingunni felast bæði andóf og lýðræðisvæðing, internetið, opinn hugbúnaður og samfélagsleg verkfæri eru notuð til að búa pekkingarflæði, pátttöku og samstarfi, athöfnum og sköpun skilvirkt umhverfi par sem skaparar (e. makers) geta fengist við próun, miðlað öðrum og átt samskipti, um sumt eftir aðstæðum á hverjum stað (Blikstein, 2013; Blum-Ross o.fl., 2019; Fab Foundation, 2021; Gershenfeld, 2012; Halverson og Sheridan, 2014; Kristín Dýrfjörð o.fl., 2019).

Fab lab-smiðjur voru opnaðar íslenskum almenningi árið 2008 og eru nú átta talsins (Fab Lab Ísland, 2021) en yfir tvö púsund á heimsvísu (Fab Foundation, 2021). Eitt starfssvið peirra tekur til menntunar og skóla með kennslu og pjónustu fyrir bæði kennara og nemendur. Allmargir grunn- og framhaldsskólar hafa nýtt sér pessa fræðslu og sumir próað eigin smiðjur, innleitt stafræna tækni og 
spreytt sig á kennsluháttum sem henta pessu nýja fræðslusniði. Aukinn áhugi skólafólks og kennara birtist í fræðslu, stuðningi, samvinnu og tilraunum sem miða að stofnun sköpunarsmiðja í skólum.

Fjölbreytileiki náms- og kennsluhátta hefur aukist í kjölfar tæknibyltingar síðustu áratuga og orðið mörgum hvati til skapandi vinnubragða (Sigrún Björk Cortes o.fl., 2016). Stafræn hönnunartól og skapandi vinna hafa verið nýtt til að efla með nemendum getu til sköpunar og trú á hana (Chang o.fl., 2019). Frumkvöðlar í notkun stafrænnar tækni í leikskólum segja tæknina geta eflt nám barna sé hún notuð á markvissan og skapandi hátt (Anna Elísa Hreiðarsdóttir, 2019) og ýmsir angar próunarstarfs á leikskólastigi vísa í sömu átt (Fjóla Porvaldsdóttir, 2018; Karl Jeppesen og Svala Jónsdóttir, 2006; Torfi Hjartarson og Svava Pétursdóttir, 2019). Pá kom fram áhugi skólafólks á sköpunarsmiðjum í rannsókn Sólveigar Jakobsdóttur o.fl. (2019) og rannsókn á fjórum tilvikum sköpunarsmiðjustarfs í íslensku samhengi menntunar sýndi að par var nemendum veitt nokkuð svigrúm til að próa eigin hugmyndir og útfærslur (Kristín Dýrfjörð o.fl., 2019).

Til pess að greina vald og atbeina í námi og kennslu í anda sköpunarsmiðja við skólana prjá er litið til skilgreiningar á eflandi kennslufræði. Hún byggir á hugtökum Bernstein (2000), flokkun og umgerð, sem snúast um vald í kennslustofunni. Með pví að greina hversu stíf umgerð er um kennslu og nám og að hvaða marki hlutverk kennara og nemenda greinast að má greina fjórar birtingarmyndir kennslufræðilegrar nálgunar í skólastarfi; mótsagnakennda, stýrandi, framsækna og eflandi kennslufræði. Í eflandi kennslufræði skarast hlutverk nemenda og kennara, nemandinn fær leiðsögn og stuðning en ræður mestu um viðfangsefni, próun hugmynda, framkvæmd og útfærslur (Svanborg R. Jónsdóttir, 2012, sjá Mynd 1).

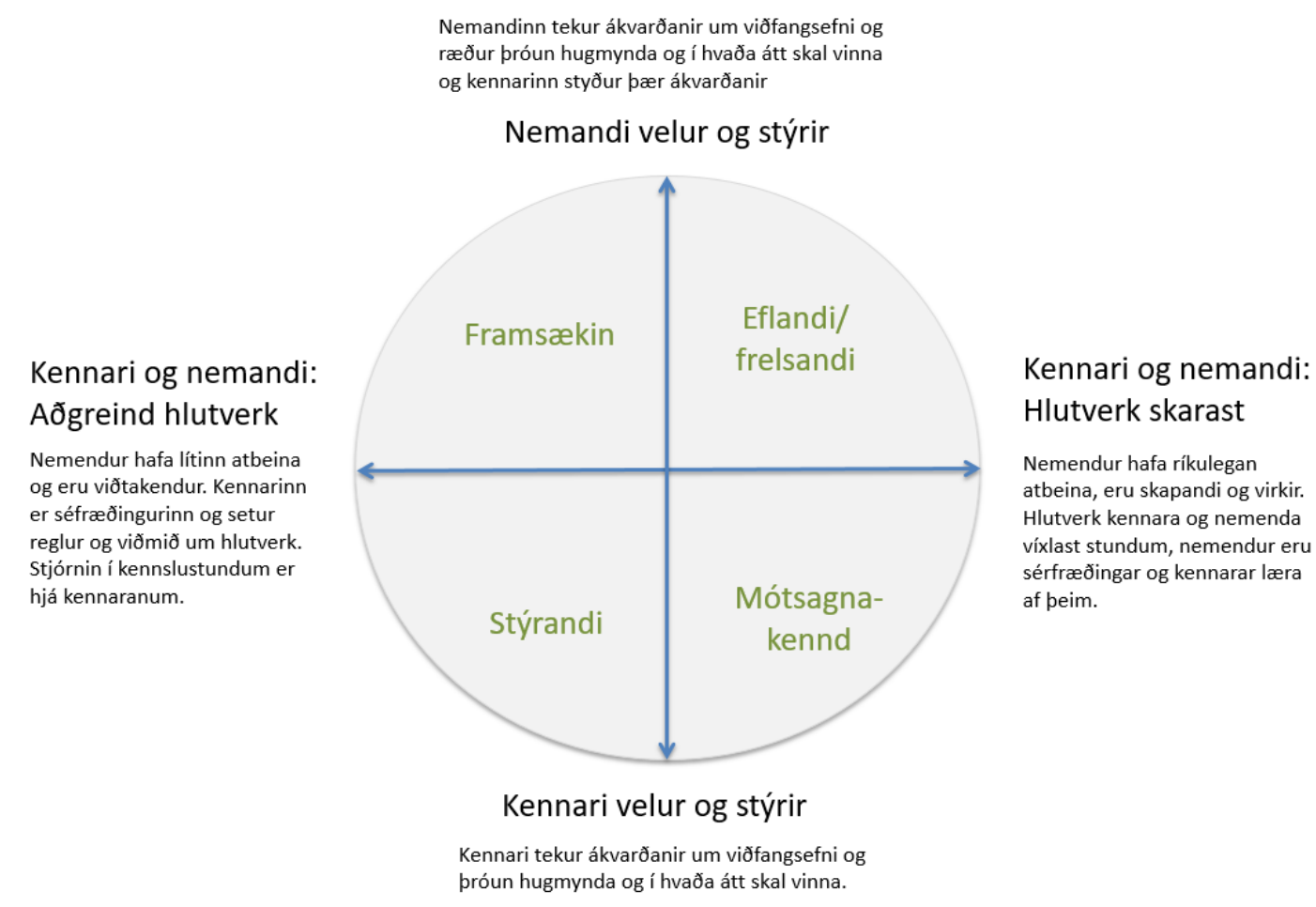

Mynd 1. Greiningarlíkan um birtingarmyndir kennslufræði eftir umgerð og flokkun hlutverka í kennslu og námi (Svanborg R. Jónsdóttir, 2012).

Með eflandi kennslufræði er leitast við að efla frumkvæði og sjálfstæði nemenda og færa vald frá kennaranum til nemandans. Líkt og í sköpunarsmiðjum færir hún nemendum atbeina í eigin námi og ætlar peim að læra með pví að finna upp og búa til hluti (Schad og Jones, 2019) en bent hefur verið á að sköpunarsmiðjur geti valdeflt ungt fólk til að verða umbreytingarafl í sínu samfélagi (Johnson o.fl., 2015). 


\section{Breytingastarf og starfshættir í íslenskum grunnskólum}

Yfirgripsmikil rannsókn á starfsháttum tuttugu grunnskóla (Gerður G. Óskarsdóttir, 2014) leiddi í ljós skólastarf markað bæði tregðu til breytinga og viðleitni til að beita nútímalegum kennsluháttum. Bein kennsla, kennarastýrðar aðferðir og einstaklingsverkefni í vinnubókum einkenndu víða kennsluhætti. Pá má nefna að kennsluaðferðir reyndust fjölbreyttari í teymiskennsluskólum en bekkjarkennsluskólum, kennarar par unnu meira saman og voru ánægðari með bæði skipulag og stjórnunarhætti en kennarar í bekkjarkennsluskólunum. Í ljós kom að áhrif nemenda á eigið nám voru lítil og umræður, hópvinna eða formleg samvinna fátíð. Nemendur sögðu nám sitt einkennast af að taka við efni frá kennurum, glósa og fást við æfingar í verkefnabók, en lítið væri um val. Rannsakendur ályktuðu að almennt væri hlutdeild nemenda í mótun skólastarfsins meira í anda 20. aldar en framtíðarsýnar alpjóðlegra stefnuskjala um sjálfstæði og hæfni nemenda á 21. öldinni. Upplýsinga- og tæknimennt átti sinn sess en kom lítið við sögu í öðrum námsgreinum. Tölvur voru frekar notaðar til að styðja nám og styrkja ríkjandi kennsluhætti fremur en að leita nýrra leiða (Sólveig Jakobsdóttir o.fl., 2014). Kennsluhættir í list- og verkgreinum reyndust með öðrum hætti en almennt í rannsókninni, par höfðu nemendur frekar tækifæri til að tileinka sér pekkingu og færni og beita henni jafnóðum en í bóklegum greinum. Flestir nemendur í rannsókninni sögðust hafa gaman af list- og verkgreinum en hefðbundnar námsgreinar póttu mikilvægastar. Pá kom fram að stefnumörkun sveitarfélaga væri fremur fylgt í umgjörð en í kennsluháttum (Gerður G. Óskarsdóttir o.fl., 2014).

Rannsóknir á umbóta- og breytingastarfi sýna að til að innleiða megi nýjungar í skólastarf purfa margir flóknir pættir að vinna saman (Fullan, 2019; Helga Sigríður Pórsdóttir og Anna Kristín Sigurðardóttir, 2020; Rogan, 2007; Svanborg R. Jónsdóttir og Allyson Macdonald, 2019). Samvirkni er talin mikilvæg til að ná árangri í umbótastarfi en hún birtist í vinnumenningu par sem hugarfar og athafnir einstaklinga og hópa miða að sama takmarki (Fullan, 2019). Niðurstöður Helgu Sigríðar Pórsdóttur og Önnu Kristínar Sigurðardóttur (2020) bentu til að meiri líkur væru á samvirkni í próun og umbótum í skólastarfi par sem stjórnendur veita faglega forystu, kennarar eru hafðir með í ráðum, unnið er eftir hugmyndafræði um faglegt lærdómssamfélag og samskipti skóla og fræðsluyfirvalda byggja á trausti og fagmennsku.

\section{Аðferð}

Við höfundar, nokkrir rannsakendur í Rannsóknarstofu um upplýsingatækni og miðlun (RANNUM) og Rannsóknarstofu um skapandi skólastarf (RASK) á Menntavísindasviði Háskóla Íslands, komum að próunarverkefninu um sköpunarsmiðjur sem ráðgjafar og rannsakendur. Rannsóknin er fjölpætt og byggir á eigindlegum gögnum sem verður safnað öll prjú árin sem verkefninu eru ætluð. Við beitum nálgun eigindlegra aðferða par sem leitast er við að fá innsýn í reynslu fólks, viðhorf og hugsun og setja í samhengi við viðfangsefni rannsóknarinnar (Creswell, 2013). Athyglin beinist að völdum páttum í próunarverkefninu: Uppeldis- og kennslufræði, stjórnun, kennslu- og námsrými, tækni, samskiptum, atbeina nemenda og sköpun. Leitast er við að greina einkenni og áhrifapætti í próun verkefnisins fyrsta árið, hvernig próunarstarf um smiðjur fellur að grunnskólastarfi, og hvernig ýta má undir og styðja pað starf. Reynt er að draga fram upplifun og skilning starfsfólks á innleiðingu kennsluhátta sem einkenna sköpunarsmiðjur, viðhorf til próunarverkefnisins, mat starfsfólks á ávinningi af verkefninu og áskorunum sem pví fylgja.

\section{Pátttakendur}

Pátttakendur eru skólastjórar, verkefnisstjórar og kennarar skólanna priggja. Engir nemendur tóku pátt í pessum fyrsta hluta rannsóknarinnar.

\section{Gögn}

Gagna var einkum aflað með vettvangsathugunum og viðtölum. Vefur verkefnisins var rýndur ásamt Facebook-síðu á pess vegum og umsókn um styrk til Reykjavíkurborgar. Gögnum var safnað saman á Teams-svæði rannsóknarhópsins. 


\section{Vettvangsathuganir}

Fylgst var með menntabúðum sem haldnar voru í tvö til prjú skipti á hvorri önn petta fyrsta skólaár en par gat allt starfslið skólanna priggja valið örnámskeið og fræðslu um margvíslega sköpunarsmiðjuvinnu. Teknar voru ljósmyndir og skráðar nótur um aðstæður og samskipti. Fundarnótur og fundargerðir af fundum verkefnisstjórnar og stærri samráðsfundum eru hluti af gögnum. Verkefnisstjórar, einn frá hverjum skóla, hittust vikulega og verkefnisstjórn, sem í sitja auk verkefnisstjóranna skólastjórar skólanna priggja, hittist á eins til tveggja mánaða fresti. Rannsakendur, einn eða fleiri, sátu marga pessara funda.

\section{Viðtöl}

Einstaklingsviðtöl við skólastjóra og verkefnisstjóra og rýnihópaviðtöl við tvö teymi kennara í hverjum skólanna priggja voru tekin á tímabilinu frá í nóvember 2019 fram í janúar 2020, samtals 12 viðtöl. Viðtölin voru tekin upp og afrituð. Reynt var að draga fram viðhorf og væntingar í upphafi verkefnisins, spurt um væntingar til sköpunarsmiðja í skólastarfinu, ávinning af verkefninu og hvernig pátttakendur teldu æskilegast að innleiðing og próun sköpunarsmiðja færi fram. Einnig var spurt um hindranir og styðjandi pætti, nýtingu rýma í skólunum, stuðning og utanumhald með verkefnum. Pá var rætt um helstu tilraunir og kennsluhugmyndir kennara tengdar verkefninu.

\section{Gagnagreining}

Rannsakendur hittust reglulega, ræddu gögn jafnóðum og merktu við áhugaverða pætti i brennidepli rannsóknarinnar. Næstu skref fólust í að draga fram pemu sem greind voru í fjóra flokka: Samstarfsverkefnið Austur-Vestur, Sýn á verkefnið og tækifæri, Áhugi, breytingavilji og hindranir og Samspil við námsgreinar grunnskólans.

\section{Siðferðilegir pattir}

Miðað er við pá meginreglu að enginn sem tekur pátt í rannsókninni hljóti skaða af (Sigurður Kristinsson, 2013). Viðmælendum var gerð grein fyrir að engir persónugreinanlegir pættir kæmu fram við framsetningu á niðurstöðum. Peir undirrituðu og veittu sampykki fyrir að taka mætti upp viðtölin, afrita og nýta sem gögn. Miðað er við að peir geti dregið gögn um sig til baka ef peir kjósa. Nöfn skólastjóra eru notuð við tilvitnanir í pá, með sampykki peirra en annars eru notuð gervinöfn. Rannsakendur hafa einir aðgang að vettvangsnótum, upptökum og afritunum viðtala en deila með skólasamfélagi skólanna priggja peim lærdómi, sem peir draga af verkefninu, á reglulegum ráłgjafafundum pau prjú ár sem verkefninu er ætlað að vara.

\section{Niðurstöður - Hugsjónir og fræði í framkvæmd}

Hér verður dregið fram hvað einkennir framkvæmd verkefnisins um sköpunarsmiðjur fyrsta árið, viðhorf, afrakstur og hindranir sem birtust í gögnunum.

\section{Samstarfsverkefnið Austur-Vestur}

Vorið 2019 fékk próunarverkefnið Austur-Vestur: Sköpunar- og tæknismiðjur í Ingunnarskóla, Vesturbæjarskóla og Selásskóla myndarlegan styrk úr Próunar- og nýsköpunarsjóði skóla- og frístundaráðs Reykjavíkur í tengslum við átak borgarinnar um nýja menntastefnu, Látum draumana rætast. Verkefnið felur í sér viðbrögð skólanna priggja við ákalli skólasamfélagsins, kennara, nemenda, foreldra og skólayfirvalda eftir námsumhverfi sem stuðlar að aukinni pekkingu og færni til nýsköpunar og lausnaleitar. Tilgangurinn er að próa kennsluhætti í takt við nýja tíma til að ýta undir fjölbreytni í námi, auka flæði milli námsgreina og tengja margbreytileg verkefni við daglegt líf og veruleika nemenda pannig að pau veki áhuga, séu krefjandi, efli færni og víðsýni. Stefnt er að pví að opna augu nemenda fyrir fjölbreyttum tækifærum sem bíða peirra og skapa vettvang sem reynir á hæfni peirra og hugvit. Lykilpáttur í verkefninu er að móta sköpunarsmiðjur sem bjóða upp á fjölbreytta kennsluhætti og vinnu par sem nemandinn er í forgrunni (Ingunnarskóli o.fl., 2019). 


\section{Prír skólar-prír heimar}

Hver skólanna priggja hefur ákveðin sérkenni hvað snertir skólagerð, áherslur í kennsluháttum, tækjavæðingu og möguleika fólgna í húsakynnum til að koma fyrir búnaði og vinnurýmum sköpunarsmiðja. Rætt var við stjórnendur um einkenni hvers skóla.

Vesturbæjarskóli hefur frá upphafi pótt nýstárlegur og framsækinn, nokkuð í peim anda sem um var rætt hér í inngangsköflum. Við hönnun skólabyggingarinnar hefur verið litið til blöndunar árganga og samvinnu með ákveðnum sveigjanleika í rýmisnotkun, sjónásum á milli kennslusvæða og nýtilegum gangsvæðum utan við stofur. Lögð hefur verið áhersla á sampættingu og skapandi starf og umtalsverða reynslu af samvinnu um slík verkefni er að finna við skólann. Pegar nýtt stjórnendateymi tók við fyrir nokkrum árum var ráðist í próunarátak um teymiskennslu og í kjölfarið innleiðingu á spjaldtölvum í skólastarfið en tækjakostur pótti rýr og beiting upplýsingatækni í kennslustundum lítil. Ný viðbygging við skólann er nú komin í gagnið með stórum sameiginlegum námssvæðum, björtum kennslustofum og útikennslusvæði á paki. Kennslustofa næst opnu skólasafni hefur verið helguð sköpunarsmiðjustarfi undir handarjaðri verkefnastjóra í verkefninu og kennara en einnig fer smiðjustarf fram í öllum kennslurýmum skólans. Áhersla á fjölbreytta kennsluhætti er mikil og kennarar áhugasamir um nýjungar tengdar sköpun og nýrri tækni.

Í Ingunnarskóla fer skólastarfið fram í opnum rýmum sem rúma fjölmenna nemendahópa. Bygging skólans tók mið af hugmyndum hönnunarhóps um aldursblöndun, teymisvinnu og sveigjanlega kennsluhætti og ruddi brautina fyrir opnar skólabyggingar. Áhersla er lögð á sampætt pemaverkefni, nýsköpunarmennt og aðrar skapandi greinar. List- og verkgreinar fengu fremur lítil rými við hönnun byggingarinnar en áttu að fléttast saman við aðrar námsgreinar og flæða um skólann og inn í víðar heimastofur nemenda. Teymisvinna kennara er ráðandi en dregið hefur úr blöndun hópa pvert á árganga. Sumarið 2020 voru opin miðrými inni á milli heimasvæða hverra tveggja árganga afmörkuð betur en áður. Par á að finna stað skapandi starfi í list- og verkgreinum, nýsköpunarmennt og sköpunarsmiðjum eftir kringumstæðum og pörfum aldursstiga.

Í Selásskóla hefur frá upphafi verið unnið í skapandi pemavinnu og um skeið var mikil áhersla á pemavinnu tengda skólasafni enda var skólinn um tíma próunarskóli Reykjavíkur á sviði skólasafna. Kennsluhættir hafa pó færst í hefðbundnari farvegi. Áhugi er á að stuðla að breytingum og skólinn er pátttakandi í mörgum próunarverkefnum. Haustið 2018 kom til starfa við skólann margreyndur skólasafnskennari og fékk skólann til pátttöku í verkefninu. Hún er mikill áhugamaður um opna kennsluhætti og nýja tækni, vill efla notkun spjaldtölva við skólann og hefur lagt drög að breytingum á tölvuveri næst skólasafninu. Par á að koma fyrir smiðju sem loka má af til að verja búnað og efnivið og stýra í tengslum við safnið. Vỉ gangarými eru í skólanum, fjöldi nemenda vel viðráðanlegur og töluverðir möguleikar til sveigjanleika í kennslu hvað rými snertir. Skólasafnskennarinn tók við stjórn skólans haustið 2020 en við safninu hefur tekið kennari með sömu hugmyndir um próunarstarf og hér var lýst.

\section{Háleit sýn, hugsjónir og takifari}

Sýn skólastjórnenda í rannsókninni kom fram í viðtölum, athugunum á fundum og í menntabúðum ásamt vefgögnum og styrkumsókn skólanna priggja.

Margrét skólastjóri í Vesturbæjarskóla lýsti sinni sýn á pessum nótum:

Sköpunarsmiðjur í mínum huga er að við höfum aðstöðu og að börnin geti unnið skapandi verkefni sem pau fá að stýra svolítið mikið, pau ráði svolítið ferðinni í sköpuninni, í útfærslu verkefna. Við getum boðið peim upp á pá aðstöðu, ef ég vil gera myndband, eða nota einhverja tækni, ég vil byggja einhverja prótótýpu, pá get ég gert pað.

Hún sagðist sjá fyrir sér að verkefnið gæti leitt til aukinnar fjölbreytni í kennsluháttum og aukið sköpun: „... meiri sköpun og opnari leiðir fyrir krakkana, pau finni sjálf sínar leiðir, fái að velja verkefni, velja leiðir um pað hvernig pau skili af sér.“ 
Guðlaug í Ingunnarskóla sagði vinnu peirra með sampættingu og pemu í skólanum vera í anda sköpunarsmiðja sem byðu upp á leið til að styðja kennslu og nám:

... pað eru náttúrulega ekki sköpunarsmiðjur, heldur eru pað meira bara fjölbreyttari verkefni og sú nálgun hefur verið hérna lengi. Pað sem okkur langar að gera núna er að byggja upp smiðjur, pað sé skapandi efniviður og auðvelda kennurum og nemendum að hafa pessi gögn til staðar á öllum svæðunum til að geta nýtt sér í tengslum við allt nám.

Hún sagðist vonast til að sjá petta kveikja í fólki, að bæði kennarar og börn sæju sér hag í að vinna á fjölbreyttan hátt.

... að hægt og sígandi eignumst við svona smiðjur sem mæta pörfum kennaranna. Fyrst og fremst verður áhuginn að koma frá kennurunum. Að verkefnið verði til pess að fleiri sjái hjá sér hag í að nýta svona hlutbundið efni og meiri sköpun og meiri tækni. Sjái tækifæri og hag, fyrst og fremst að pað langi og vilji. [...] Ef enginn hefur áhuga á [fullt af smiðjum með fullt af dóti] pá gerist ekkert.

Í svipaðan streng tók Sigfús í Selásskóla sem sagði petta verkefni snúast fyrst og fremst um hag nemenda og að peir fengju menntun sem gerði pá færa um að lifa og starfa í nútímasamfélagi:

... pegar peir útskrifast og koma út á vinnumarkaðinn, pá er allt annar veruleiki sem blasir við peim, en við okkur. Pað sem fyrir manni vakir er að búa nemendunum tækifæri til að takast á við pann veruleika sem blasir við peim pegar út er komið. Pað er sköpun, samskipti, samvinna og frumkvöðlamennt, gervigreind sem gerir pað að verkum að pá breytast sum störf og önnur hverfa. Pá reynir á krakkana, að pau hafi hugmyndaflug til að búa sér til störf. Petta eru allt lykilatriði sem skipta rosalega miklu máli, fyrir utan náttúrulega að lesa, skrifa og reikna.

Parna og í umsóknargögnum má sjá hjá stjórnendum háleitari sýn og meiri áhuga en í viðtölum við kennarateymin. Peir hafa miklar væntingar sem snúast um fjölbreytni og að gera nemendur tæknifæra, skapandi og framtakssama einstaklinga til að takast á við síbreytilegt og margslungið samfélag.

\section{Ljósmæður eða garðyrkjukonur?}

Í upphafi skipaði hver skólanna priggja verkefnisstjóra til að leiða innleiðingu sköpunarsmiðja í sínum skóla. Verkefnisstjórarnir eru allir konur og minna ýmist á ljósmæður að taka á móti nýju barni eða garðyrkjukonur að sá hugmyndum og sjá til pess að pær verði að veruleika. Pær fá hér nöfnin Auður, Hallgerður og Puríður. Î viðtölunum við pær komu fram præðir og pemu sem varpa ljósi á viðhorf peirra og hvernig pær vinna, heildarsýn á leiðarljós og tilgang verkefnisins. Líkt og skólastjórarnir sjá pær fyrir sér aukna fjölbreytni, nútímalega kennsluhætti, skapandi viðfangsefni og nemendamiðuð verkefni.

\section{Tilgangur og leiðarljós}

Puríður sagðist vonast til að sköpunarsmiðjuvinnan hvetti kennarana til að færa sig frá kennslubókum og nær hæfniviðmiðum:

Við förum frá bóknámi, sem er mjög leiðinlegt og oáhugavert, yfir í verkefnatengt nám og pemu, sem miðast við ákveðin hæfniviðmið sem hver nemandi getur sóst eftir að ná á sínum hraða.

Ég held pað sé mjög gott að koma til móts við svona fjölbreyttan nemendahóp í pannig verkefni, sem er peirra sköpun, pau purfa að afla sér upplýsinga og setja fram og pau purfa að læra saman, petta tekur á svo mörgum páttum svona verkefni. 
Parna má sjá væntingar um að próunarstarfið auki atbeina nemenda, virkni peirra og áhrif í náminu. Puríður taldi vinnubrögð í smiðjum bjóða upp á að nemendur hefðu meira um sitt nám að segja, gætu ákveðið hvernig verkefni væru útfærð og sýnt tiltekna hæfni. Hallgerður talaði á svipuðum nótum um aukinn atbeina með auknu vali og meira sjálfstæði:

Væntingar mínar eru fyrst og fremst að nemendur fái aðeins meira sjálfstæði í náminu og hafi val um margar leiðir í sínum viðfangsefnum. Ég held að pað sé fjölbreytni í leiðum að markmiðum, sem mér hefur fundist skorta og ég held að með pví að bjóða upp á pað, pá komum við til með að vera með ánægðari nemendur.

Hún sagði hugmyndafræði sköpunarsmiðjanna snúast um „að vinna á skapandi hátt með nemendum“. Í sama streng tók Auður sem væntir pess að sköpunarsmiðjur auki fjölbreytni og skapandi vinnu:

[Smiðjur] verði til pess að auka fjölbreytni í skólastarfinu, að fólk sjái sér hag í pví að nýta pessi svæði, pá er ég ekki endilega að tala bara um eitthvað tölvutengt eða eitthvað tæknidæmi, heldur bara skapandi vinnu, hvort sem pað er í kubbum eða iPöddum.

Auður vonaðist til að starfið í smiðjurýmunum yrði lifandi og að kennararnir „tileinki sér pau eða eigni sér pessi rými, petta verði ekki bara mitt rými eða deildarstjórans“. Pannig mátti greina samhljóm í viðhorfi verkefnisstýra og skólastjórnenda, væntingar um fjölbreyttari kennsluhætti, val nemenda og sköpun.

\section{Gródurhús hugmynda og rektunarstarf}

Til pess að koma hugmyndum um sköpunarsmiðjur á framfæri við kennarana og hvernig pær gætu birst í framkvæmd voru haldnar menntabúðir par sem öllu kennaraliði skólanna priggja var stefnt saman í rúmar tvær klukkustundir tvisvar til prisvar á hvorri önn til skiptis í skólunum. Par var boðið upp á fjölbreytt hlaðborð ríkulegra veitinga og stuttra kynninga um margs konar smáforrit, tól og tæki, aðferðir og verkefni sem miðuðust við skapandi vinnu nemenda, ýmist með stafrænni tækni eða ápreifanlegri útfærslum. Vandað var til menntabúðanna og innlegg valin af kostgæfni svo að pau næðu sem best til kennaranna. Flytjendur voru ýmist leiðandi kennarar og kennsluráðgjafar á pessu sviði skólastarfs eða samkennarar að miðla af eigin reynslu. Eftir hverjar menntabúðir var send út könnun par sem kennararnir voru spurðir hvað hefði gagnast peim og hvað peir myndu vilja fá í næstu menntabúðum.

Sjá mátti í viðtölum og á vikulegum samráðsfundum að verkefnisstýrurnar höfðu mikla trú á menntabúðunum sem gróðurhúsi hugmynda par sem sáð væri fræjum og pau látin spíra í heppilegu andrúmslofti. Hallgerður taldi sig sjá viðfangsefni frá menntabúðum kveikja áhuga kennaranna á nýjum tækjum og skapandi vinnu eftir rafrænum leiðum:

Peir eru að telja í sig kjark að nota sumt af pví en ég sé strax fólk sem hefur áhuga, til dæmis með Sphero-kúlurnar, að pær sáu pær og fengu að prófa, voru spenntar og vildu prófa petta hér.

Puríður taldi menntabúðirnar gefa kennurunum tækifæri til að prófa sköpunarsmiðjuvinnu með vali um alls konar verkefni og að eftir pví sem kennararnir kynntust fleiri viðfangsefnum og reyndu slík verkefni oftar myndu kennsluhættir breytast. Hún taldi pessa vinnu purfa að vera stöðuga og endurtekna til að opna fyrir nýja hugsun hjá kennurunum: „Peir verða að fá tækifæri til pess að [...] gera petta oft, tæknin hefur, pað er einhvern veginn búið að vera hræðsla við petta.“

Eftir fyrstu menntabúðirnar áttuðu verkefnisstýrurnar sig á að próa pyrfti framboðið og laga að pví sem kennararnir kölluðu eftir. Auður sagði að pær væru að spá í hvernig best væri að skipuleggja næstu menntabúðir: 
Við vorum að hugsa um að hafa pað pannig að pað myndu allir velja sér fyrirfram prjár smiðjur. Pá gætum við svolítið stýrt pví, ef enginn hefur áhuga á einhverju, pá erum við ekkert að bjóða upp á pað.

Sumir kennaranna sögðu henni að allt hefði verið svo spennandi og peir viljað vera lengur í öllu sem var í boði. Í kjölfarið var ákveðið að hafa hverja kynningu lengri og ítarlegri, fólk gæti pá „dýpkað sig og lært eitthvað betur“.

Verkefnisstýrurnar töldu að pað pyrfti mörg skref til að ná markmiðunum sem stefnt væri að. Hallgerður sagði: „Maður lærir að maður parf að vera polinmóður. Við hugsuðum petta sem priggja ára verkefni." Pær sáu líka að fleira en menntabúðirnar gæti stutt innleiðingu verkefnisins og ræktun fræja sem par væri sáð. Jafningjafræðsla væri öflug leið til að kveikja áhuga kennara og hvetja pá til dáða. Pær hvöttu kennara sinna skóla til að deila verkefnum með samkennurum og komu á laggirnar hópi á Facebook par sem pær benda á eða segja frá skapandi skólastarfi. Kennarar í skólunum premur sýna einnig myndir og segja frá vinnu sinni í anda sköpunarsmiðja. Pær sögðu kennara trega til að deila með öðrum en pegar peir sæju aðra segja frá ýtti pað undir að peir gerðu pað sama.

Allar töldu pær hlutverk sitt sem leiðtoga og ráðgjafa mikilvægt en að samt pyrfti borgin að efla kennsluráðgjöf á pessu sviði:

Og nú erum við komnar með pessa prjá kennsluráðgjafa og maður er strax farinn að sjá hvað pær eru að vinna flott saman. Pær fara jafnvel út í skóla og bjóða skólahópum til sín.

En við purfum að gera miklu meira af pessu.

Pær lýstu hvernig ráðgjafarnir gætu kynnt stuðning og búnað í nýsköpunar- og tækniverinu Mixtúru með ýmsu móti til að kennarar gætu séð „,hvernig petta er og pú veist hvað, hvað er til og hvað er hægt að gera“.

Einnig kom fram að stundaskrá gæti stutt betur við skapandi skólastarf með tímum sem væru lengri en 40 mínútur og að tilteknar valstundir kæmu í góðar parfir. Puríður sagði stundaskrá við sinn skóla vera of hamlandi fyrir verkefnatengt og skapandi nám: „[Við purfum] sveigjanlega stundatöflu, stundataflan okkar er mjög hamlandi, pannig að ég myndi vilja sjá miklu meira að við værum að vinna eitthvað pema." Húsnæði pótti lítil hindrun enda spennandi tækifæri í öllum skólunum premur til að koma upp rýmum par sem bjóða má upp á efnivið, tól og stuðning til að nota við sköpun. Margir pættir hefðu áhrif á ræktunarstarfið, að innleiða og framkvæma hugsjónir um skapandi og nútímalegt skólastarf, próa pað og styðja.

\section{Hlutverk i mótun og samvirkni margra pátta}

Hlutverk verkefnisstýranna virtist enn í mótun. Allar höfðu pær öðrum verkefnum að sinna. Ein sagðist „búin að vera svona eitthvað verkefnisstjóri og eitthvað deildarstjóri“ og önnur „deildarstjóri með svona sérverkefni og svo kem ég að nemendamálunum“. Pær töldu sig geta komið betur að stuðningi við kennarana með pví að koma inn í kennslustofur og hjálpa peim af stað með einhverja nýjung par til að peir yrðu sjálfbjarga.

Meiningin er að ég fari inn í bekkina [...] pað er að mótast. Best er ef ég get verið bara með kennurunum og peir geta svo tekið við, ég hjálpa peim að komast af stað með einhver verkefni og peir taka svo við.

Pá töldu pær teymisvinnu innan skólanna greiða fyrir innleiðingu og frampróun verkefnisins. Teymin pyrftu að deila með öðrum kennurum pví sem pau væru að áorka:

Рað er mjög mikilvægt að hvetja teymi til að segja hvað pau eru að gera, við höfum ekki verið nógu dugleg í pví. Á starfsmannafundum að sýna og segja frá einhverju sem pau hafa verið að gera hefur gengið vel. Til að aðrir geti fengið hugmyndir og séð hvað er verið að gera. 
Verkefnisstýrurnar nefndu marga pætti sem hefðu áhrif á innleiðingu tækni og kennsluhátta sem fylgja smiðjunum. Til pess að peir spiluðu saman pyrftu peir allir að virka og styðja hver annan. Pær sáu að pær gætu haldið áfram að styðja kennarana en að skipulag og stjórnun skipti líka máli. Til dæmis væri pað á valdi skólastjóranna að vinna með stundaskrá og annað vinnufyrirkomulag starfsfólks. Stuðningur skólastjóra og áhugi skiptu miklu: „Stjórnendur náttúrulega verða bara að vera inni í pessu og vita út á hvað petta gengur og skilja hvað parf að gera." Leiðtogahlutverk skólastjóranna væri lykilbáttur og fælist í að tryggja pá samvirkni sem pyrfti til að festa verkefnið í sessi. Próunarvinnan væri fjölpætt og pó að stuðningur stjórnenda væri mikilvægur pyrftu frumkvæði og pátttaka kennara líka að koma til:

... kennaranna frumkvæði að vilja fara pangað, pannig að við purfum að stökkva af stað pegar par að kemur en petta verður að vera soldið líka frumkvæði kennaranna, ekki bara stjórnendur að koma og segja peim hvernig hlutirnir eiga að vera.

Verkefnisstýrurnar hafa allar staðfasta trú á skapandi skólastarfi og á samtali og samstarfi við alla hagsmunaaðila. Pær höfðu hins vegar áhyggjur af að sumir kennarar í skólunum væru fastir í venjum, efuðust og fyndu til vanmáttar gagnvart verkefninu. Pó voru pær bjartsýnar á að hafa mætti áhrif á hugarfar með pví að vinna með pá pætti sem hömluðu og ýta undir pá vaxtarsprota sem pær sáu hjá flestum.

\section{Áhugi kennara, breytingavilji og hindranir}

Allir kennarar skólanna priggja taka pátt í próunarverkefninu. Hér segir frá niðurstöðum úr sex viðtölum við tvö teymi umsjónarkennara frá hverjum skóla. Hvert kennarateymi kennir einum árgangi og er samvinna mikil. Pemu sem birtust við greiningu viðtalanna má sjá á Mynd 2.

\begin{tabular}{|c|c|}
\hline \multicolumn{2}{|r|}{ Áhugi kennara, vilji til breytinga og hindranir } \\
\hline Pema & Einkenni \\
\hline $\begin{array}{l}\text { Áhugi, bakgrunnur } \\
\text { og reynsla }\end{array}$ & $\begin{array}{l}\text { Áhugi á verkefninu var mismikill. Viơmælendur sem sýndu mestan áhuga voru með bakgrunn ílistum, } \\
\text { verkgreinum og/eđa upplýsingatækni. }\end{array}$ \\
\hline $\begin{array}{l}\text { Fjölbreyttir } \\
\text { kennsluhættir }\end{array}$ & $\begin{array}{l}\text { Allir töldu mikilvægt að̃ nota fjölbreyttar aðferđir við nám og kennslu, brjóta upp hefőbundna kennslu og } \\
\text { bjóđa nemendum upp á marga verkefnakosti. }\end{array}$ \\
\hline $\begin{array}{l}\text { Hæfni próuð } \\
\text { í sköpunarsmiðjum }\end{array}$ & Nemandi teiknar sitt furðudýr, tekur af pví mynd og hljóðsetur með smáforritinu ChatterPix Kids. \\
\hline $\begin{array}{l}\text { Tími og } \\
\text { stuđ̃ningur }\end{array}$ & $\begin{array}{l}\text { Mörg bróunarverkefni eru í skólunum og margt sem barf að sinna. Stjórnendur mættu stundum sýna } \\
\text { meiri áhuga og hafa oftar umræður um verkefnið. Miðlægt kerfi borgarinnar er oft pungt í vơfum og } \\
\text { stundum djúpt á tækniaðstoð. }\end{array}$ \\
\hline
\end{tabular}

Mynd 2. Áhugi kennara, vilji til breytinga og hindranir

\section{Áhugi, bakgrunnur og reynsla}

Misjafnt var hversu langt hvert teymi var komið í vinnu sinni með sköpunarsmiðjur. Áhugi á verkefninu var mismikill og ljóst að viðmælendur sem sýndu mestan áhuga höfðu bakgrunn í listum, verkgreinum og/eða upplýsingatækni. Peir kennarar höfðu mikla reynslu af að vinna skapandi vinnu með nemendum sínum, sumir mest með hefðbundinn efnivið en aðrir stafræna tækni. Peir síðastnefndu höfðu sérstakan áhuga á upplýsingatækni og höfðu sótt ráðstefnur, námskeið og kynningar á pví sviði og kynntu sér oft tölvutengd málefni á netinu. Aðrir höfðu ekki pennan sama bakgrunn og reynslu en allir sýndu kennararnir próunarverkefninu áhuga og sáu í pví möguleika til að mæta pörfum nemenda með fjölbreyttari kennsluháttum og auknu vali um viðfangsefni og leiðir. Sumir kennarar lýstu reynsluleysi og óöryggi, einkum gagnvart tækninni. Eitt kennarateymi nefndi að pótt 
pau kynntust mörgu spennandi í menntabúðum, kæmi fróðleikurinn að takmörkuðu gagni væri hann ekki nýttur strax:

Pú veist, maður er alveg, já, petta er ógeðslega sniðugt pegar maður lærir petta en ef maður fer ekki beint að nota petta pá bara gleymir maður pví hvernig maður á að gera hlutina.

Pótt sumir segðust ekki hafa komið nálægt vinnu með sköpunarsmiðjur höfðu allir reynslu af skapandi starfi með börnum.

\section{Mikilvagi fjölbreyttra kennsluhátta}

Kennarar sem rætt var við töldu allir mikilvægt að nota fjölbreyttar aðferðir við nám og kennslu. Kennsla byggðist hugsanlega um of á bóknámi og mætti taka pað til endurskoðunar. Brjóta pyrfti upp hefðbundna kennslu og bjóða upp á marga verkefnakosti. Reynslan sýndi að börn hefðu gaman af sköpun:

... við bara fáum svo mikið frá börnunum pegar pau fá að skapa eitthvað, pá sjáum við allt í einu eitthvað gerast, í staðinn fyrir að pau setjist niður, pau fá vinnubók og pað bara deyr eitthvað, við sjáum bara einhverjar heilasellur deyja, sko, en parna bara, pað lifnar allt við, pú veist, pað bara, pau bara brosa og pað er bara áhugi og pau bara stökkva upp í sætunum sínum bara: Sjáðu! คað að pau fái tækifæri til pess að skapa gerir bað að verkum að allt nám getur farið parna fram, við getum kennt peim allt í gegnum sköpun.

Kennararnir töldu að sumir nemendur myndu njóta sín betur pegar tæknin kæmi til og að koma pyrfti til móts við parfir sem flestra. Nefnd voru dæmi um nemendur sem voru tregir til að skrifa en viljugri að gera pað í tölvu. Sum börnin áttuðu sig ekki á hvað pau lærðu mikið pegar pau ynnu með spjaldtölvur, peim fyndist pau vera að leika sér. Aukin spjaldtölvueign skólanna og reynslan sýndi að nám gegnum tölvur höfðaði betur en bóknám til margra nemenda og voru drengir nefndir sérstaklega af tveimur teymanna. Jafnframt kom fram að lærdómur gæti fest betur í minni barna pegar pau fengju að vera og gera, vinna sjálfstætt og ráða ferðinni í stað pess að læra af bók. Eitt teymið nefndi að vinna með tækni og tölvur gæti nýst börnum sem væru full föst í ákveðnum ramma:

[Petta], að peir styrkleikar sem hver og einn hefur fái bara að njóta sín. Líka petta, að krakkar sem eru kannski meira ferkantaðir, peir hafi gott af pessu líka og petta sé mikilvægt fyrir [pá] líka, ég held að samfélagið sé að próast pað hratt og pað er að verða svo tæknilegt, við megum ekki sleppa pessari nálgun af pví að petta er eitthvað sem mun nýtast peim í framtíðinni. Börnin hafa líka mjög mikinn áhuga á pessu og petta er mjög mikið uppbrot og eitthvað skemmtilegt og verklegt og pau eru svona spennt.

Líkt og fram hefur komið leggja allir kennararnir, sem við ræddum við, skapandi verkefni fyrir nemendur sína. Eitt kennarateymið var með sérstakt horn fyrir skapandi efnivið og sagði börnin vön slíkri vinnu. Kennararnir segðu bara: Petta er viðfangsefnið, parna er efniviðurinn og pá vita börnin öll að hverju pau ganga og geta unnið sjálfstætt. Aðrir nefndu að pað væri önnur hugsun sem færi í gang pegar pau ynnu úr ýmsum hráefnum og pað væri alltaf skemmtilegt. Рað mætti sjá gleði hjá börnunum pegar pau fengju að læra gegnum leik og sköpun og lærdómur festist betur í minni:

Pú getur nálgast svo margt á skapandi hátt ... Pað er náttúrulega mjög auðvelt að fara í bara eins og vinnubók og svo tökum við blaðsíðu fyrir blaðsíðu og svörum einhverjum spurningum en pað er líka spurning hvað situr eftir ... Ég var með pessa krakka í fyrsta bekk, við vorum með svolítið smíðaverkefni og pau muna pað en pau muna ekki eftir hvaða stærðfræði pau voru að gera. Pau muna frekar hvað pau voru að gera í höndunum.

\section{Hafni sem börn próa gegnum vinnu i sköpunarsmiðjum}

Kennararnir nefndu mikilvæga hæfni sem börn próuðu með sér gegnum skapandi vinnu. Pau öðluðust hæfni til að prófa sig áfram par til pau fyndu réttu lausnina. Slík vinna krefðist pess að pau gerðu tilraunir og reyndi á rökhugsun, samvinnu og getu til að skrásetja. Eitt kennarateymi sagðist vilja að 
börnin kynntust vinnubrögðum nýsköpunar með pví að taka hugmynd og gera hana að veruleika. Pau pyrftu pá að spyrja sig spurninga: Af hverju tókst petta ekki? Hvernig getum við gert betur? Pannig lærðu pau gegnum tilraunir sínar.

Kennararnir sögðust vilja rækta sjálfstæði með börnum í stað pess að mata pau á upplýsingum, að pau gætu sótt sér upplýsingar og skapað eitthvað í kringum verkefni sín. Sköpunarsmiðjur gætu ýtt undir sköpunargleði, samvinnu og ígrundun, og gert börnin færari um að framkvæma sjálf. Gegnum sköpun fengju börnin tilfinningu fyrir efnum og hvernig mætti nýta pau. Hjá kennurunum kom fram að margir óttast að börn einangrist við vinnu sína í tölvum. Pað var ekki reynsla kennaranna sem rætt var við. Peir sögðu pvert á móti samvinnu barna vera meiri en pegar pau sætu öll með bók eða væru að leysa skrifleg verkefni. Hér hjálpuðust pau að og ynnu saman. Pau töluðu saman, spáðu og spekúleruðu. Ef pau sæju eitthvað áhugavert hjá öðrum vildu pau prófa líka. Pau sem byggju yfir meiri tölvufærni hjálpuðu peim sem væru skemmra á veg komin. Pannig lærðu pau hvert af öðru. Flestir kennaranna sem rætt var við voru sammála um að börn væru fljót að ná tökum á tækninni. Oft væru pau fljótari en kennararnir og fengju parna tækifæri til að sýna hvað pau gætu og hjálpa hvert öðru. Мeð pessu móti fengju börn sem ekki væru sterk á bóklega sviðinu að sýna getu sína. Kennarar pyrftu stundum að láta af peirri hugsun að peir pyrftu að kunna allt best og meta samvinnu nemenda í tölvuvinnunni að verðleikum.

\section{Tíminn og stuðningur}

Margir kennaranna sögðu knappan tíma valda pví að peir væru ekki almennilega byrjaðir að vinna að próunarverkefninu. Í skólunum væru mörg próunarverkefni í gangi í einu og margt annað sem pyrfti að sinna. Erfitt gæti verið að finna tíma til að sinna pessu öllu. Kennarar söknuðu pess einnig að fá ekki ákveðinn tíma til að velta fyrir sér möguleikum:

Okkur vantar oft svona grúskið og petta að geta setið saman og bara: Hvernig gerðir pú petta og eitthvað svona. Ég sakna pess pínu.

Mörgum kennurum fannst vanta meiri stuðning við innleiðingu sköpunarsmiðjanna. Sumir söknuðu ráðgjafa til að leiða kennarana áfram, vera peim til halds og trausts, alla vega í upphafi. Einhvers sem kæmi með tillögur að viðfangsefnum og upplýsingar um hvernig pau tengdust hæfniviðmiðum.

K3: Já, ég myndi alveg, alveg einmitt piggja pað ef pað kæmi ein manneskja í bara eina kennslustund eða tvær.

K1: Sem myndi svona aðeins hjálpa manni af stað í pessu.

K3: Já, leiða mann í gegnum bara og vera með krökkunum.

K1: Maður myndi sjá einhvern í aksjón að gera petta, kannski.

K2: Mér finnst petta vera rosalega mikill pakki, pað er svo margt sem er hægt að gera og petta að sampætta við allt, pað eru alls konar leiðir og pað er svo margt. Petta er svolítið svona stórt, og mér, mér líður svona eins og petta pyrfti bara að vera kúrs í háskóla eða eitthvað.

Eitt kennarateymi taldi að taka mætti pessa vinnu inn sem sérstaka lotu tengda nýsköpun og fjölbreyttum kennsluháttum. Annað kennarateymi nefndi að taka mætti verkefnið inn sem sérgrein líkt og list- og verkgreinar. Pá nefndi einn að bjóða mætti upp á námskeið í háskóla um sköpunarsmiðjuvinnu. Annað kennarateymi nefndi pað sama og sagðist einn kennari ekki myndi hika ef taka mætti meistaragráðu á pessu sviði. Fleiri kennurum fannst vanta lengri námskeið en pau sem voru í boði í menntabúðum til pess að kynnast betur vinnu með tækni sem nýta mætti í starfi með börnum.

Pað er kannski ekkert víst að við fáum alla kennara, sem sagt, til pess að gera petta, ef að við gerum petta á pessum hraða, pú veist, pað vantar pá, sem sagt, inn í skólana manneskju sem að getur, pið vitið, sagt hvað er í boði, pú veist og fá pessa sem að pora ekki, fá pá til að læra, en petta yrði að vera skikkað námskeið. 
Sumir nefndu að stjórnendur skólanna mættu sýna próunarverkefninu meiri áhuga og hafa meiri umræður um verkefnið á kennarafundum til að halda fólki við efnið. Einnig pyrftu kennarar að fá betri tækifæri til að kynna vinnu sína í tengslum við verkefnið.

Kennarar voru mismeðvitaðir um hlutverk verkefnisstjóra í sínum skóla og hvernig peir gætu nýtt sér aðstoð peirra. Pó voru margir sem hrósuðu peim og sögðu pá mjög hvetjandi:

Hún er alltaf boðin og búin að hjálpa okkur og maður finnur pað alveg að hún er að hvetja okkur til pess að próa okkur áfram. Hún er líka mjög ánægð pegar maður segist ætla að fara að gera eitthvað, pá verður hún rosa glöð. †að er eins og maður sé að gera henni geðveikan greiða!

Miðlæga kerfið hjá borginni sögðu ýmsir vera pungt í vöfum. Tekið gæti langan tíma að fá tækniaðstoð par sem einn maður sinnti mörgum skólum. Einn skólanna beið mánuðum saman eftir að Reykjavíkurborg fjarlægði borðtölvur svo hægt væri að nýta rýmið fyrir sköpunarsmiðju. Sumir kennararnir töldu að gera pyrfti ráð fyrir sköpunarsmiðjum í stundatöflu, líkt og sérgrein. Aðrir sáu tækifæri til að tengja sköpunarsmiðjur peim viðfangsefnum sem verið var að vinna með. Sumir töldu að erfitt yrði að vinna verkefni sem kynnt voru í menntabúðum með stórum hópi. Pví pyrfti að skipuleggja vinnuna pannig að kennarar gætu verið með fámennari hópa í sköpunarsmiðjum. Sumir nefndu að sköpunarsmiðjur krefðust mikils undirbúningstíma og pyrfti að gera ráð fyrir pví.

\section{Kennslufræðilegar birtingarmyndir og námsgreinar grunnskólans}

Hér verður sagt frá peirri kennslufræðilegu sýn sem birtist á pessu fyrsta ári í peim verkefnum og viðfangsefnum sem sjá má á vefsíðu verkefnisins, pví sem deilt hefur verið á Facebook-síðu peirra og pví sem rannsóknarhópurinn hefur séð í heimsóknum og viðtölum. Greina má fimm flokka verkefna sem brugðið er upp í Mynd 3 ásamt stuttum lýsingum. 
Flokkar verkefna sem rannsakendur hafa greint í heimsóknum, viðtölum, á vefsetri og Facebook-sí̋u

\begin{tabular}{|c|c|c|c|}
\hline Flokkur & Efniviður & Áhersla & Dæmi \\
\hline \multirow{2}{*}{$\begin{array}{l}\text { Hönnunaráskorun } \\
\text { prautalausn }\end{array}$} & $\begin{array}{l}\text { Verôlaust/lítið efni } \\
\text { Án tækni }\end{array}$ & $\begin{array}{l}\text { Hönnun } \\
\text { Samvinna } \\
\text { Nýsköpun }\end{array}$ & $\begin{array}{l}\text { Spaghettiturn } \\
\text { Skóhönnun }\end{array}$ \\
\hline & \multicolumn{3}{|c|}{$\begin{array}{l}\text { Kennari setur upp áskorun meฮ̃ ákveđ̃num takmörkum, til dæmis hvađ̃ snertir magn eđ̃a efniviô. } \\
\text { Dæmi: Nýtilegir inniskór úr dagblőđum og límbandi. Nemendur vinna saman ađ̃ lausnaleit og hönnun. }\end{array}$} \\
\hline \multirow{2}{*}{$\begin{array}{l}\text { Tækni } \\
\text { og hönnun }\end{array}$} & $\begin{array}{l}\text { Rafmagnsvörur } \\
\text { Verôlaust/lítið efni }\end{array}$ & Rafrásir & $\begin{array}{l}\text { Jólakort } \\
\text { Tannburstavélmenni } \\
\text { Teiknivélmenni }\end{array}$ \\
\hline & \multicolumn{3}{|c|}{ 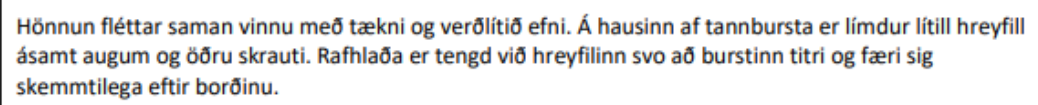 } \\
\hline \multirow{2}{*}{$\begin{array}{l}\text { Stafræn } \\
\text { hönnun }\end{array}$} & $\begin{array}{c}\text { iPad } \\
\text { Smáforrit }\end{array}$ & Stafræn sköpun & $\begin{array}{l}\text { Talandi furoudýr } \\
\text { Grænskjá-myndir }\end{array}$ \\
\hline & \multicolumn{3}{|c|}{ Nemandi teiknar sitt furð̃udýr, tekur af pví mynd og hljóøsetur með̃ smáforritinu ChatterPix Kids. } \\
\hline \multirow{2}{*}{$\begin{array}{l}\text { Unnið̃ } \\
\text { međ̃ sögur }\end{array}$} & $\begin{array}{l}\text { Verôlaust/lítiô efni } \\
\text { Sögur }\end{array}$ & $\begin{array}{l}\text { Læsi } \\
\text { Sköpun } \\
\text { Hönnun } \\
\text { Samvinna }\end{array}$ & $\begin{array}{l}\text { Gosi } \\
\text { Grisirnir prír } \\
\text { Gullbrá og birnirnir }\end{array}$ \\
\hline & \multicolumn{3}{|c|}{$\begin{array}{l}\text { Sagan er lesin og rædd áóur en ráôist er í hönnun í verỗlausan eđ̃a verôlítinn efniviô. Nemendur vinna } \\
\text { saman og búa til kofa grísanna priggja úr ýmsum efniviỡi. Hárblásari leikur hlutverk úlfsins sem reynir aô } \\
\text { blása kofana um koll. }\end{array}$} \\
\hline \multirow{2}{*}{$\begin{array}{l}\text { Sampætting } \\
\text { námsgreina }\end{array}$} & Ýmis efniviður & $\begin{array}{l}\text { Námsgreinar } \\
\text { Pekking } \\
\text { Hönnun } \\
\text { Stafrænt læsi }\end{array}$ & $\begin{array}{l}\text { Pema um víkinga } \\
\text { Pema um hafið }\end{array}$ \\
\hline & \multicolumn{3}{|c|}{$\begin{array}{l}\text { Pemaverkefni meỗ bein tengsl vĩ̃ kennslugreinar grunnskólans. Nemendur hanna og skapa á grunni } \\
\text { pekkingar sem peir ő̂llast eđ̃a aflađ̃ sér. Afrakstur rannsóknarvinnu i landsnámspema sýndi fatnađ̃ } \\
\text { víkinga, skip peirra og híbýli. }\end{array}$} \\
\hline \multirow{2}{*}{$\begin{array}{l}\text { Stafræn miðlun } \\
\text { (virk vinnutæki) }\end{array}$} & Padlet & $\begin{array}{l}\text { Læsi } \\
\text { Bekkjarandi }\end{array}$ & $\begin{array}{l}\text { Bókameđ̃mæli } \\
\text { Hvađ̃ gerđum viő } \\
\text { i skólanum? }\end{array}$ \\
\hline & \multicolumn{3}{|c|}{$\begin{array}{l}\text { Kennari setur upp siốu i Padlet par sem nemendur mæla meố bókum hver fyrir aốra. Í veirufaraldri taka } \\
\text { nemendur aô deila pvi sem peir eru ađ̃ gera i skólanum meô peim sem sitja heima. }\end{array}$} \\
\hline
\end{tabular}

Mynd 3. Flokkar verkefna í anda sköpunarsmiðja.

Í mörgum verkefnanna má greina af lýsingum kennara að peim er ætlað að pjálfa hönnun, samvinnu og nýsköpun. Í pemum sem nemendur unnu um hafið og víkinga voru auðsæ tengsl við samfélagsfræði og náttúrufræði og í vinnu með rafrásir og rafmagn tengsl við náttúrufræði. Í leikrænni framsetningu og alls kyns hönnun sáust tengsl við íslensku í vinnu með læsi, ljóð og sögur, framsögn og tjáningu. Greinilegt var að fjölbreyttir kennsluhættir, skapandi vinna, samvinna nemenda og rökhugsun voru kennslufræðileg áhersluatriði. Kennararnir telja aðra hugsun fara í gang pegar nemandi færir sig frá borði og bók en velta líka fyrir sér hvernig peir geti komið smiðjuvinnunni fyrir í skólastarfinu og hvað megi taka út á móti: „Pú getur ekki endalaust bætt við bókum og bætt við pessu og hinu. En petta kemur með fjölbreytileikann inn [í smiðjuvinnuna] fyrir vikið, kannski.“

Við bárum lýsingar kennara á verkefnavinnu að líkani Svanborgar (2012) um birtingarmyndir kennslufræði til að átta okkur á hvaða kennslufræðilega nálgun mætti greina í kennslu tengdri próunarverkefninu petta fyrsta starfsár. Í peim mátti sjá allt frá kennarastýrðum verkefnum par sem hvert skref var forskrifað yfir í skapandi hönnun úr opnum efniviði par sem reyndi ríkulega á atbeina nemenda. 
Á Mynd 4 eru verkefni sem kennarar töldu til sköpunarsmiðjuvinnu og greind voru eftir pví að hvaða marki nemendur fengu að ákveða viðfangsefni og útfærslur og pví hversu sterk aðgreining var á hlutverkum nemenda og kennara. Sjá má af lýsingum að kennarar leitast við að auka sjálfstæði og atbeina nemenda með pví að gefa peim ákvörðunarrétt yfir útfærslum og framsetningu en pó eru allnokkur merki um kennarastýringu. Stýrðu verkefnin virðast snúast um að kenna og pjálfa færni, eins og í stærðfræði eða forritun eða kynna möguleika og virkni verkfæra. Eftir pví sem verkefnin verða opnari felur vinnan í sér meiri ígrundun, rannsóknir á hugmyndum og efniviði, lausnaleit og samvinnu, verkefni par sem nemendur hanna skip og híbýli víkinga er opnara en verkefni sem snýst um að búa til tannburstaskrímsli eftir uppskrift. Pá er fengist við raunsannari úrlausnarefni, eins og að búa til stutta mynd eða hanna brú.

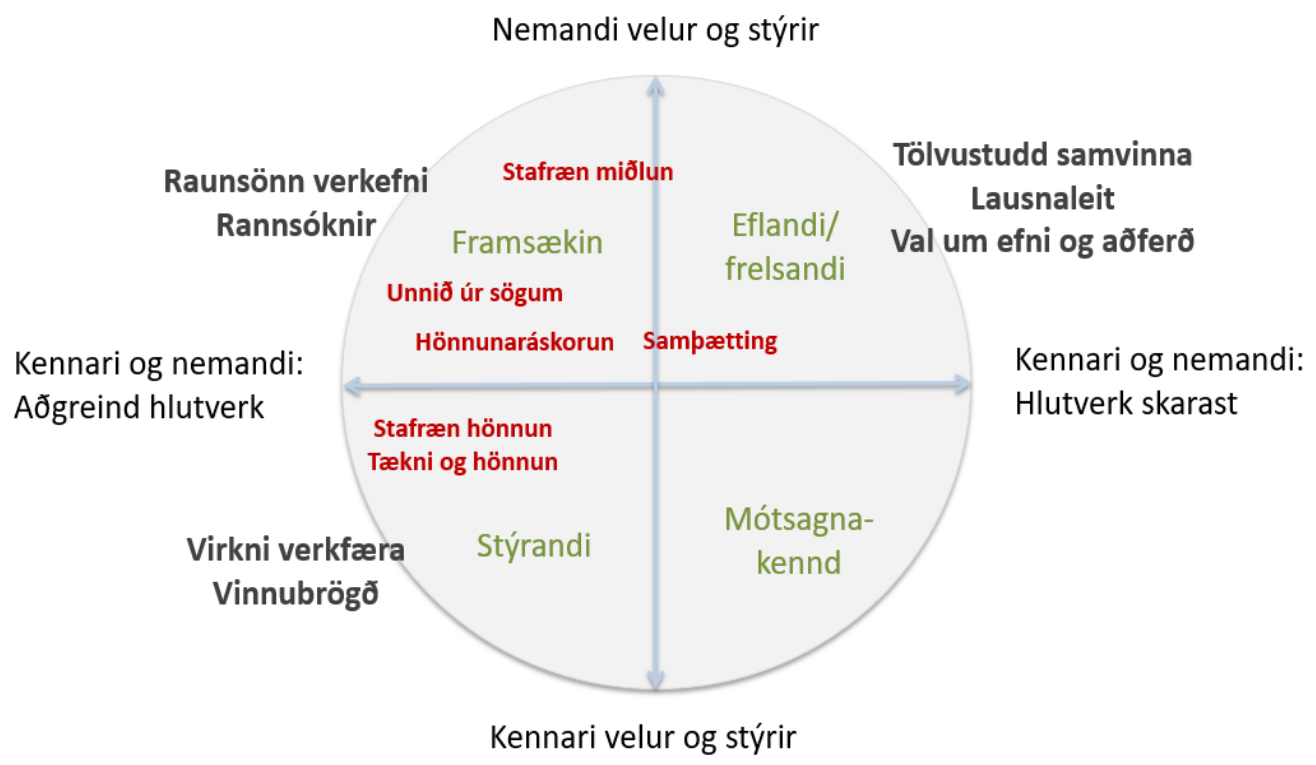

Mynd 4. Verkefnaflokkar eftir umgerð og hlutverkum í kennslu og námi (sjá Svanborg R. Jónsdóttir, 2012).

Sú spurning vaknar hvort vinnan við innleiðingu smiðjuvinnu og tækninýjunga verði að fylgja ákveðnu ferli, hvort kenna purfi vinnubrögð áður en ráðist er í opnari sköpun. Petta er pó ekki einhlítt pví mörg verkefnin einkenndust af áskorunum par sem nemendur höfðu ekki endilega unnið með efniviðinn og verkfærin áður. Kennslufræðileg nálgun í peim tilvikum er pá fremur sú að pegar vanti verkfæri og aðferðir til að glíma við ný úrlausnarefni eða nýjan efnivið sé rétti tíminn til að læra á og tileinka sér pá hluti.

Ljóst virðist að kennararnir stefna að eflandi kennslu, peir vilji efla sköpunina, tjáninguna og samskiptin, og að nemendur hafi meira um nám sitt að segja, meira val um viðfangsefni og fjölbreyttari leiðir til að tjá og miðla pví sem peir hafa lært. Kennslufræðileg sýn í pví tilliti er skýr. Aftur á móti telji sumir peirra sig skorta pekkingu, leiðsögn, stuðning og svigrúm til að ganga jafn langt í pá átt og peim pætti æskilegast.

\section{Samantekt og umræður - Hálfnað er verk pá hafið er}

Í rannsókninni var leitað svara við hvað einkenndi starfið í próunarverkefni priggja grunnskóla um innleiðingu sköpunarsmiðju fyrsta starfsárið. Eins og ráða má af fræðilegum inngangskafla og niðurstöðum geta sköpunarsmiðjur haft fjölpætt gildi í menntun með áherslu á atbeina nemenda og lausnaleit, teymisvinnu, gagnrýna sýn og skapandi hugsun. Pessi sjónarmið koma skýrt fram í styrkumsókn og viðtölum okkar höfunda við stjórnendur og starfslið skólanna priggja. Viðmælendur sjá í sköpunarsmiðjum tækifæri til að ýta undir skapandi vinnubrögð, auka atbeina nemenda, stuðla 
að tæknilæsi, efla stafrænt læsi, pjálfa fjölhátta miðlun og skapa pverfagleg námstækifæri í anda sampættingar. Stjórnendur, verkefnastjórar og kennarar búa flestir að dýrmætri reynslu af teymisvinnu, pverfaglegu samstarfi og sköpun í skólastarfi og áhugi er á að auka slíka kennsluhætti og samvinnu. Einnig kom fram áhugi á að dýpka samfélagsvitund nemenda og stuðla að pátttöku peirra í tæknivæddu lýðræðissamfélagi (Blikstein, 2013; Kristín Dýrfjörð o.fl., 2019; Schad og Jones, 2019).

Kennararnir eru misákafir og mislangt á veg komnir í tækninotkun og sveigjanlegum kennsluháttum í samvinnu við aðra og gæta parf að vilja peirra og getu til breytinga (Sólveig Jakobsdóttir o.fl., 2014; Svanborg R. Jónsdóttir og Allyson Macdonald, 2019). Svigrúm fyrir próunarstarf á nýju sviði er takmörkunum háð og skipulag og annríki skólastarfsins hindrun. Skólastjórnendur, verkefnastjórar og áhugasamir kennarar um verkefnið purfa að beita sér af elju og hugkvæmni fyrir nýjungum eigi pær að festa rætur (Helga Sigríður Pórsdóttir og Anna Kristín Sigurðardóttir, 2020). Tæknivæðing og hugmyndir um breytta kennsluhætti eru liðir í flóknu samspili fjölmargra pátta sem greina parf og skilja (Fullan, 2019; Mason, 2008; Rogan, 2007). Álykta má að efla purfi samvirkni peirra pátta sem greina mátti á pessu fyrsta ári og beina áhrifapunga peirra í sömu átt. Par purfi skólastjórnendur og verkefnastjórar að vera leiðandi (Helga Sigríður Pórsdóttir og Anna Kristín Sigurðardóttir, 2020). Skerpa purfi hlutverk og sýnileika verkefnisstýra og leitast við að tryggja virk samtöl, jákvæð viðhorf, áhuga og breytingavilja kennara.

Reynsla í kennaraliðinu og hefð fyrir teymisvinnu og skapandi starfi er góður jarðvegur fyrir starf í anda sköpunarsmiðja. Húsnæði býður líka upp á áhugaverð rými undir smiðjustarf, oftast í góðum tengslum við kennslustofur og skólasöfn. Bent var á ýmsar leiðir til að finna sköpunarsmiðjum stað í stundatöflum. Verkefnisstýrurnar virðast brenna fyrir verkefninu, eru í færum til að veita skýra leiðsögn um framhaldið og skólastjórnendur sjá í verkefninu pýðingarmikið tækifæri til að ýta undir teymisvinnu, tæknivæðingu og bætta kennsluhætti á breiðum grunni til langframa. Pá pykir samstarf á milli skólanna, við frumkvöðla í skólastarfi og rannsakendur á Menntavísindasviði Háskóla Íslands hafa verið gagnlegt. Hugmyndir pær sem sjá mátti í markmiðum verkefnisins um sampættingu, samfélagstengsl, gagnrýni og sköpun falla vel að ýmsum áherslum í kennaramenntun, sumum meginpáttum námskrár, menntastefnu og ríkjandi orðræðu um próun skólastarfs enda eiga pær djúpar rætur í uppeldis- og menntavísindum (Eisner, 2002; Gerður G. Óskarsdóttir o.fl., 2014; Priestley og Biesta, 2013; Svanborg R. Jónsdóttir og Rósa Gunnarsdóttir, 2017).

Kennsluhugmyndir sem voru kynntar og prófaðar í verkefninu má telja kennslufræðilegar vísbendingar um færar leiðir til að tengja sköpunarsmiðjur daglegu skólastarfi. Lýsingar kennara endurspegla hvernig verkefnavinna í anda sköpunarsmiðja laðar fram atbeina nemenda og ýtir undir lausnaleit, ígrundun og sköpun. Samkeppni um athygli, tíma og vinnuframlag kennara er pó mikil og pessum árangri parf að fylgja vel eftir. Bæta parf upplýsingaflæði og yfirsýn á próunarstarfið, koma árangursríku starfi kennara sem best á framfæri jafnt innan skólanna sem utan og tryggja að verkefnastjórar geti með framtaki sínu veitt pá leiðsögn og pann stuðning sem kennarar parfnast í fyrstu. Pá má, eins og dæmin frá fyrsta ári verkefnisins sanna, hafa mikinn stuðning af menntabúðum, frumkvöðlum og kennsluráðgjöfum sem hafa beitt sér fyrir sköpunarsmiðjum í skólastarfi. Sumir kennaranna virðast helst treysta á samkennara, ráðgjafa og menntabúðir en aðrir sækja leiðsögn á netið. Hvetja mætti kennara til pátttöku í samfélögum kennara um nýja tækni og skapandi starf. Margt bendir líka til að efla megi tæknipjónustu og jafnvel nýta stafræn samskipti og umsjónarkerfi til að auðvelda kennurum leikinn.

Áform skólanna í verkefninu endurspegla áræði og framsýni í samfélagslegu og kennslufræðilegu tilliti. Nokkrir hafa riðið á vaðið og aðrir purfa að fylgja á eftir, móta sér skoðun á verkefninu og ákveða hvert skuli stefnt. Til pess parf hvatningu, skýra leiðsögn og gott svigrúm. Tækifærin eru mörg og jarðvegurinn víða frjór en fræin parf að grípa, gróðursetja og vökva par til nýgræðingurinn hefur fest rætur og náð að dafna. Vaka parf yfir próunarstarfinu með samstilltu og stöðugu átaki til langs tíma með skýra framtíðarsýn. Hugmyndavinna og umræða í námssamfélagi er hafin og áhugavert verður að sjá hvernig pví vindur fram. Geta og frelsi til athafna ásamt hæfilegum stuðningi, gagnrýni og hvatningu eru forsendur sköpunar og á pað líka við um starfspróun til móts við tækninýjungar og breytta kennsluhætti. 


\section{Implementation of makerspaces in three Icelandic compulsory schools: Praxis and pedagogy, the first steps}

In the past few decades we have seen huge technological advancements, demographic shifts, economic expansion and profound cultural changes. The generations now growing up have been immersed in digital technology from their birth. We do, in our modern contemporary society, need a shift in education towards teaching and learning, where students are more active and creative participants, having the agency to shape their own learning. This research presents the first year of three in a school development project on implementing makerspaces to support such a shift in three compulsory schools in Reykjavík, the capital city of Iceland: Ingunnarskóli, Selásskóli and Vesturbæjarskóli (2019).

Our study aims to increase understanding of what is needed for the innovation and design thinking of makerspaces to set roots in compulsory school practice and the pedagogies underlying "making" in school contexts. We want to identify characteristic and influential factors in the developmental process during the initial year of collaboration and implementation, as well as mapping how participants look upon and experience the project.

\section{Theoretical background}

We build our understanding and interpretation of the findings on theories and research on school and educational development (Fullan, 2019; Gerður G. Óskarsdóttir, 2014; Helga Sigríður Pórsdóttir and Anna Kristín Sigurðardóttir, 2020; Mason, 2008), digital technology and development of fab-labs and makerspaces (Blikstein, 2013; Halverson and Sheridan, 2014; Litts, 2015), creativity (Eisner, 2002), agency (Emirbayer and Mische, 1998; Moore, 2016; Svanborg R. Jónsdóttir og Rósa Gunnarsdóttir, 2017) and emancipatory pedagogy (Svanborg R. Jónsdóttir, 2012; Svanborg R. Jónsdóttir and Rósa Gunnarsdóttir, 2017).

\section{Method}

The research is grounded in qualitative methodology, where we seek to gain insight into participants' attitudes and experiences and connect these to the focus of the research (Creswell, 2013). The research data consists of field notes, interviews with principals, project managers, two teams of teachers in each of the three schools, as well as grant application documents, the schools' application for funding, a public project website and a Facebook site where staff members share their efforts and experiences in making.

\section{Findings}

The findings reflect how we as researchers see or interpret coherent and contradictory factors affecting the process of introduction and initial implementation during the first year of the project. Many different influential factors were at play. Support and interest of principals, proactive efforts of project managers, attitudes, experience and skills of teachers, how the project and its importance was understood, the organization of the school timetable and conversations and solidarity were all issues that appeared to make a difference in the implementation of the makerspaces.

Many steps, actions, attitudes and different roles characterised the project in the first year. Principals and project managers shared a genuine belief in the potential of the developmental project to change teaching approaches towards the needs of modern education by enhancing creativity, supporting technological literacy, integrating knowledge, encouraging teamwork and giving students ample agency. We see the all- female project managers both as "midwives" helping to deliver a precious baby and as "gardeners" sowing seeds and tending to them as they sprout and grow. A key effort in this 
respect was to conduct educamps for all three schools, twice or three times over each school term.

Some of the teacher teams showed enthusiasm and readiness to embrace the affordances of makerspaces while others were more hesitant or reluctant. Some indicators revealed how the flow of information and conversations between teachers, project managers and principals had not reached all the teaching staff and was seen by some members as a top-down venture. We saw many interesting examples of integrative and creative school projects built on the makerspace approach, both digital productions and hands-on constructions from recyclable or other tangible materials. Our analysis of the pedagogical modes emerging in those projects indicated that they varied from being teacher controlled, to being progressive, involving less teacher control, and even being emancipatory in character with ample student agency and creativity. Many positive steps have been taken in this first year of implementation and this needs to be followed up with constructive conversations and exchanges between all stakeholders to ensure that all elements and factors at work in the project culminate in a momentum coherent enough to move this developmental undertaking in the right direction.

\section{Conclusions}

Many positive steps were taken in this first year and they need to be purposefully followed up with constructive and active conversations between stakeholders in order to make the coherence of elements and momentum push in the intended direction.

Key words: Creativity, makerspaces, emancipatory pedagogy, digital technology, school development, coherence, educamps

\section{Um höfunda}

Svanborg Rannveig Jónsdóttir (svanjons@hi.is) er prófessor við Menntavísindasvið Háskóla Íslands. Hún lauk B.Ed.-prófi frá Kennaraháskóla Íslands 1978 með íslensku og dönsku sem aðalgreinar. Hún lauk M.A.-prófi í uppeldis- og menntunarfræðum frá Háskóla Î́slands 2005 með áherslu á nýsköpunarmennt. Árið 2011 lauk hún doktorsnámi frá Menntavísindasviði Háskóla Íslands og er titill doktorsritgerðar hennar The location of innovation education in Icelandic compulsory schools. Rannsóknir hennar snúast um nýsköpunar- og frumkvöðlamennt, námskrárfræði, skapandi skólastarf, breytingastarf og starfstengda sjálfsrýni í kennaramenntun. ORCID ID: https://orcid.org/0000-00028194-0939

Skúlína Hlíf Kjartansdóttir (shk@hi.is) er aðjúnkt við Menntavísindasvið Háskóla Íslands. Hún lauk B.Ed.-prófi frá Kennaraháskóla Íslands 1982 og eins árs diplómanámi í handlistum frá sama skóla 1983. Hún lauk B.A.-prófi í prívíddarhönnun frá Camberwell College of Art 1989 og M.A.-prófi í myndlist/skúlptúr frá Wimbledon College of Art / Kingston University. Skúlína hefur starfað sem kennari og skólastjórnandi á grunnskólaog framhaldsskólastigi. Hún leggur stund á doktorsnám við Háskóla Íslands. Kennsla hennar og rannsóknir eru á sviði list- og verkmenntunar, tæknimenntar, upplýsingatækni í menntun, fjölháttalæsi, stefnumótunar og skólapróunar. ORCID ID: https:// orcid.org/0000-0001-6817-5462

Svala Jónsdóttir (svalaj@hi.is) er aðjúnkt við Menntavísindasvið Háskóla Íslands. Hún er með próf í grafík og auglýsingateiknun frá Myndlista- og handíðaskóla Íslands og meistaragráðu í kennslufræði frá Kennaraháskóla Íslands. Hún hefur aðallega kennt verðandi leikskólakennurum, fyrst við Fósturskóla Íslands, en nú við Menntavísindasvið HÍ. Rannsóknir hennar hafa aðallega snúist um náttúrufræði og upplýsingatækni í leikskólum ásamt sköpun í skólastarfi. 
Svava Pétursdóttir (svavap@hi.is) er lektor við Menntavísindasvið Háskóla Íslands. Hún lauk B.Ed.-prófi frá Kennaraháskóla Íslands 1989 og doktorsnámi frá University of Leeds 2012. Doktorsritgerð hennar bar titilinn Using information and communication technology in lower secondary science teaching in Iceland. Rannsóknir hennar eru á sviði upplýsingatækni í skólastarfi, starfssamfélaga kennara og náttúrufræðimenntunar. ORCID ID: https://orcid.org/0000-0002-1206-8745

Torfi Hjartarson (torfi@hi.is) er lektor við Menntavísindasvið Háskóla Íslands. Rannsóknir hans beinast að skapandi vinnu með stafræna tækni í sveigjanlegu skólastarfi og hönnun bæði námsgagna og bygginga fyrir verkefnamiðað nám. Hann hóf sinn feril sem námsefnishöfundur, lauk meistaranámi frá University of Oregon 1991, stýrði Gagnasmiðju Kennaraháskóla Íslands, veitti Kennarafélagi Kennaraháskóla Íslands forystu og var í hópi ritstjóra sem stóð að stofnun Netlu - Veftímarits um uppeldi og menntun. ORCID ID: https://orcid.org/0000-0003-4382-6331

\section{About the authors}

Svanborg Rannveig Jónsdóttir (svanjons@hi.is) is a professor at the University of Iceland School of Education (IUE). She completed a B.Ed. degree at the Iceland University of Education in 1978, an M.A. degree in pedagogy from the University of Iceland and a Ph.D. from the University of Iceland, School of Education in 2011. Her thesis is titled: The location of innovation education in Icelandic compulsory schools. Her research fields are innovation and entrepreneurial education, curriculum development, creativity in education, school change and professional self-study in teacher education. ORCID ID: https://orcid.org/0000-0002-8194-0939

Skúlína Hlíf Kjartansdóttir (shk@hi.is) is an adjunct at the University of Iceland School of Education (IUE). She holds a B.Ed. degree, and a diploma in crafts education from the Iceland University of Education, a B.A. degree in 3D Design from Camberwell College of Art and a master's degree in art / site specific sculpture from Wimbledon College of Art / Kingston University. Skúlína has served as a teacher and manager at primary, lower secondary and upper secondary schools. She is currently studying for a Ph.D. at the University of Iceland. Her teaching and research interests include art \& design education, technology education, ICT in education, multimodal literacy, educational policy and practice. ORCID ID: https://orcid.org/0000-0001-6817-5462

Svala Jónsdóttir (svalaj@hi.is) is an adjunct at the University of Iceland School of Education (IUE). She has a degree from Iceland University of the Arts and a M.A. degree in pedagogy from the University of Iceland / School of Education. She has mainly taught students training to become preschool teachers, now at the University of Iceland / School of Education. Her research field has mainly been nature science and information technology with young children and creative work in schools.

Svava Pétursdóttir (svavap@hi.is) is a lecturer/assistant at the University of Iceland School of Education (IUE). She completed a B.Ed. degree from the Iceland University of Education in 1989 and a doctorate in education from the University of Leeds in 2012. The title of her thesis is: Using information and communication technology in lower secondary science teaching in Iceland. Her research interests are in the field of ICT in education, teachers' professional development and science education. ORCID ID: https:// orcid.org/0000-0002-1206-8745

Torfi Hjartarson (torfi@hi.is) is a lecturer/assistant professor at the University of Iceland School of Education (IUE). His research interests include creative applications of digital media in flexible school practice and the design of learning materials and physical learning environments for project- based work. He started out as a curriculum textbook 
writer, completed an M.Sc. degree at the University of Oregon in 1991, directed an IT and Media Center at the Iceland University of Education, led the teacher association of that institute and was one of the founding editors of Netla - Online Journal on Pedagogy and Education. ORCID ID: https://orcid.org/0000-0003-4382-6331

\section{Heimildir}

Anna Elísa Hreiðarsdóttir. (2019). Stafræn tækni í leikskólastarfi: Sjónarhorn frumkvöðla. Netla - Veftímarit um uppeldi og menntun. http://netla.hi.is/serrit/2019/menntun_barna_leik_grunn/08.pdf

Bamford, A. (2011). List-og menningarfreðsla á Íslandi. Mennta- og menningarmálaráðuneytið.

Bernstein, B. (2000). Pedagogy, symbolic control, and identity (2. útgáfa). Rowman og Littlefield.

Binkley, M., Erstad, O., Herman, J., Raizen, S., Ripley, M., Miller-Ricci, M. og Rumble, M. (2012). Defining twenty-first century skills. Í P. Griffin, B. McGaw og E. Care (ritstjórar), Assessment and teaching of 21st century skills (bls. 17-66). https://doi.org/10.1007/978-94-007-2324-5_2

Blikstein, P. (2013). Digital fabrication and 'making' in education: The democratization of education. Í J. Walter-Herrmann og C. Büching (ritstjórar), Fab Lab: Of machines, makers and inventors. Culture and media studies (bls. 203-222). Berlin De Bruyter.

Blum-Ross, A. Kumpulainen, K. og Marsh, J. (2019). Enhancing digital literacy and creativity: Makerspaces in the early years (1. útgáfa). Routledge.

Chang, Y.-S., Chen, M.Y.-C., Chuang, M.-J. og Chou, C.-H. (2019). Improving creative self-efficacy and performance through computer-aided design application. Thinking Skills and Creativity, 31, 103-111. https:// doi.org/10.1016/j.tsc.2018.11.007

Craft, A. (2001). An analysis of research and literature on creativity in education. http://www.creativetallis.com/ uploads/2/2/8/7/2287089/creativity_in_education_report.pdf

Creswell, J. W. (2013). Research design: Qualitative, quantitative, and mixed methods approaches (4. útgáfa). Sage.

Eisner, E. W. (2002). What education can learn from the arts. Í E. W. Eisner, Arts and the creation of mind (bls. 196-208). Yale University Press.

Emirbayer, M. og Mische, A. (1998). What is agency? The American Journal of Sociology, 103(4), 962-1023. http://links.jstor.org/sici?sici=0002-9602\%28199801\%29103\%3A4<962\%3AWIA>2.0.CO\%3B2-7

Fab Foundation. (2021). Fab Foundation. https://fabfoundation.org/index.html

Fab Lab Ísland. (2021). Hvað er Fab Lab? https://www.fablab.is/um-fablab/

Fjóla Porvaldsdóttir. (2018). Fikt: Námsvefur um upplýsingatækni fyrir kennara í leikskóla og á yngsta stigi grunnskóla [meistaraverkefni]. Háskóli Íslands.

Fullan, M. (2019). Nuance: Why some leaders succeed and others fail. Corwin Press.

Gerður G. Óskarsdóttir (ritstjóri). (2014). Starfshattir i grunnskólum við upphaf 21. aldar. Háskólaútgáfan.

Gerður G. Óskarsdóttir, Amalía Björnsdóttir, Anna Kristín Sigurðardóttir, Börkur Hansen, Ingvar Sigurgeirsson, Kristín Jónsdóttir, Rúnar Sigpórsson og Sólveig Jakobsdóttir. (2014). XII. Starfshættir í grunnskólum -meginniðurstöður og umræða. İ Gerður G. Óskarsdóttir (ritstjóri), Starfshattir í grunnskólum við upphaf 21. aldar (bls. 323-347). Háskólaútgáfan.

Gershenfeld, N. (2012). How to make almost anything: The digital fabrication revolution. Foreign affairs, 91(6), 42-57. http://cba.mit.edu/docs/papers/12.09.FA.pdf

Halverson, E. R. og Sheridan, K. M. (2014). The maker movement in education: Designing, creating, and learning across contexts. Harvard Educational Review, 84(4), 492-494. DOI:10.17763/HAER.84.4. 34J1G68140382063

Helga Sigríður Pórsdóttir og Anna Kristín Sigurðardóttir. (2020). Samvirkni og samvinna í próunar- og umbótastarfi. Netla - Veftimarit um uppeldi og menntun. https://doi.org/10.24270/netla.2020.2 
Ingibjörg Jóhannsdóttir, Elísabet Indra Ragnarsdóttir og Torfi Hjartarson. (2012). Sköpun: Grunnpáttur menntunar á öllum skólastigum. Menntamálastofnun og Mennta- og menningarmálaráðuneytið.

Ingunnarskóli, Selásskóli og Vesturbæjarskóli. (2019). Sköpunarsmiðjur. Samstarfsverkefni um sköpunarsmiððjur i Vesturbajarskóla, Ingunnarskóla og Selasskóla [vefsetur]. https://sites.google.com/rvkskolar.is/austurvestur/heim

Johnson, L., Adams Becker, S., Estrada, V. og Freeman, A. (2015). The NMC horizon report: 2015 K-12 Edition. http://cdn.nmc.org/media/2015-nmc-horizon-report-k12-EN.pdf

Karl Jeppesen og Svala Jónsdóttir. (2006). Upplýsingatakni i leikskóla 2. Leikskólinn İavöllur - Takninotkun [myndband, 14 mín]. Rannsóknarstofnun Kennaraháskóla Íslands - NámUST.

Kristín Dýrfjörð, Torfi Hjartarson, Anna Elísa Hreiðarsdóttir, Sólveig Jakobsdóttir, Svanborg Rannveig Jónsdóttir, Skúlína Hlíf Kjartansdóttir, Margrét E. Ólafsdóttir, Svava Pétursdóttir og Gísli Porsteinsson. (2019). Makerspaces in formal and non-formal learning contexts in Iceland. Í A. Blum-Ross, K. Kumpulainen og J. Marsh (ritstjórar), Enhancing digital literacy and creativity: Makerspaces in the early years (bls. 71-92). (1. útgáfa). Routledge.

Kumpulainen, K. og Kajamaa, A. (2021). The transformative potential of school-based makerspaces: Novel designs in educational practice. Í E. Brooks, S. Dau og S. Selander (ritstjórar), Digital learning and collaborative practices: Lessons from inclusive and empowering participation with emerging technologies (bls. 175-184). Routledge.

Litts, B. K. (2015). Making learning: Makerspaces as learning environments [doktorsritgerð, University of Wisconsin-Madison]. http://www.informalscience.org/sites/default/files/Litts_2015_Dissertation_Published.pdf

Marsh, J., Kumpulainen, K., Nisha, B., Velicu, A., Blum-Ross, A., Hyatt, D., Jónsdóttir, S. R., Levy, R., Little, S., Marusteru, G., Ólafsdóttir, M. E., Sandvic, K., Scott, F., Thestrup, K., Arnseth, H. C., Dýrfjörð, K., Jornet, A., Kjartansdóttir, S. H., Pahl, K., Pétursdóttir, S. and Thorsteinsson, G. (2017). Makerspaces in the early years: A literature review. http://makeyproject.eu/wp-content/uploads/2017/02/Makey_Literature_Review.pdf

Mason, M. (2008). What is complexity theory and what are its implications for educational change? Í M. Mason (ritstjóri), Complexity theory and the philosophy of education (bls. 32-45). Wiley-Blackwell.

Montuori, A. (2012). Creative inquiry: Confronting the challenges of scholarship in the 21st century. Futures, 44(1), 64-70. https://doi.org/10.1016/j.futures.2011.08.008

Mennta- og menningarmálaráðuneyti. (2012). Aðalnámskrá grunnskóla 2011: Almennur bluti.

Moore, J. W. (2016). What is the sense of agency and why does it matter? Frontiers in Psychology, 7, 1272. https://doi.org/10.3389/fpsyg.2016.01272

Negroponte, N. (1995). Being digital. Hodder og Stoughton.

Priestley, M. og Biesta, G. (2013). Introduction: The new curriculum. Í M. Priestley og G. Biesta (ritstjórar), Reinventing the curriculum: New trends in curriculum policy and practice (bls. 1-12). Bloomsbury.

Rogan, J. (2007). An uncertain harvest: A case study of implementation of innovation. Journal of Curriculum Studies, 39(1), 97-121. https://doi.org/10.1080/00220270500532448

Runco, M. A. og Jaeger, G. J. (2012). The standard definition of creativity. Creativity Research Journal, 24(1) 92-96. https://doi.org/10.1080/10400419.2012.650092

Sardar, Z. (2010). Welcome to postnormal times. Futures, 42(5), 435-444. https://doi.org/10.1016/j.futures.2009.11.028

Schad, M. og Jones, W. M. (2019). The maker movement and education: A systematic review of the literature. Journal of Research on Technology in Education, 52(1), 65-78. https://doi.org/10.1080/15391523.2019.1 688739

Sigrún Björk Cortes, Björgvin Ívar Guðbrandsson, Margrét Hugadóttir og Torfi Hjartarson. (2016). Skapandi skóli: Handbók um fölbreytta kennsluhatti og stafrana miðlun. https://mms.is/namsefni/skapandi-skoli-handbok-um-skapandi-skolastarf-rafbok

Sigurður Kristinsson. (2013). Siðfræði rannsókna og siðanefndir. Í Sigriððu Halldórsdóttir (ritstjóri), Handbók i aðferðafraði rannsókna (bls. 71-89). Háskólinn á Akureyri.

Sólveig Jakobsdóttir, Kristín Dýrfjörð, Skúlína H. Kjartansdóttir, Svanborg R. Jónsdóttir og Svava Pétursdóttir. (2019). Sköpunarsmiðjur í menntun ungra barna: Reynsla og viðhorf starfsfólks skóla, safna og sköpunarsmiðja. Netla - Veftimarit um uppeldi og menntun. http://netla.hi.is/serrit/2019/menntun_barna_leik_grunn/09.pdf 
Sólveig Jakobsdóttir, Torfi Hjartarson og Bergbóra Pórhallsdóttir. (2014). Upplýsingatækni í skólastarfi. Í Gerður G. Óskarsdóttir (ritstjóri), Starfshattir i grunnskólum við upphaf 21. aldar (bls. 277-321). Háskólaútgáfan.

Sternberg, R. J. og Lubart, T. I. (2002). The concept of creativity: Prospects and paradigms. Í R. J. Sternberg (ritstjóri), Handbook of creativity (bls. 3-15). Cambridge University Press.

Svanborg R. Jónsdóttir. (2012). The location of innovation education in Icelandic compulsory schools [doktorsritgerð, Háskóli Íslands]. http://hdl.handle.net/1946/7766

Svanborg R. Jónsdóttir og Allyson Macdonald. (2019). The feasibility of innovation and entrepreneurial education in middle schools. Journal of Small Business and Enterprise Development, 26(2), 255-272. https:// doi.org/10.1108/JSBED-08-2018-0251

Svanborg R. Jónsdóttir og Rósa Gunnarsdóttir. (2017). The road to independence: Emancipatory pedagogy. Sense.

Torfi Hjartarson og Svava Pétursdóttir. (2019). Förskolans digitalisering på Island: En resa som kräver mod, tid och stöd! Í Kristina Holmberg, Anniqa Lagergren og Torfi Hjartarson (ritstjórar), Lek och lärande med digitala verktyg i nordiska forrskolor: Erfarenheter från två Nordplus-projekt 2015-2019. http://norden.diva-portal.org/ smash/get/diva2:1358757/FULLTEXT01.pdf

Viereck, G. S. (1929). What life means to Einstein. The Saturday evening post. Curtis Publishing company.

Walia, C. (2019). A dynamic definition of creativity. Creativity Research Journal, 31(3), 237-247. https://doi. org/10.1080/10400419.2019.1641787

Svanborg R. Jónsdóttir, Skúlína H. Kjartansdóttir, Svala Jónsdóttir, Svava Pétursdóttir og Torfi Hjartarson. (2021).

Sköpunar- og tæknismiðjur í premur grunnskólum: Framkvæmd og kennslufræði fyrstu skrefin

Netla - Veftímarit um uppeldi og menntun. Menntavísindasvið Háskóla Íslands.

Sótt af https://netla.hi.is/greinar/2021/alm/09.pdf

DOI: https://doi.org/10.24270/netla.2021.9 